Article

\title{
Effect of the Nature and Relative Concentration of Substrate, Water Mineralization, and Storage Temperature on the Oxidants Produced by Lactoperoxidase and on Their Antifungal Activity against Penicillium expansum and Botrytis cinerea
}

\author{
Françoise Bafort ${ }^{1, *} \mathbb{D}$, Christian Damblon ${ }^{2}$, Georges C. $\operatorname{Lognay}^{3} \mathbb{D}$, Jean-Paul Barthelemy ${ }^{3}$, \\ Jean-Paul Perraudin ${ }^{4}$ and Mohamed Haïssam Jijakli ${ }^{1}$ \\ 1 Integrated and Urban Plant Pathology Laboratory, Liège University, Gembloux Agro-Bio Tech, \\ Passage des Déportés 2, 5030 Gembloux, Belgium; MH.Jijakli@uliege.be \\ 2 Structural Biological Chemistry Laboratory (SBCL), Liège University, Allée du 6 Août 11, \\ 4000 Liège, Belgium; c.damblon@uliege.be \\ 3 Analytical Chemistry Laboratory, Liège University, Gembloux Agro-Bio Tech., Passage des Déportés 2, \\ 5030 Gembloux, Belgium; Georges.Lognay@uliege.be (G.C.L.); Jean-Paul.Barthelemy@uliege.be (J.-P.B.) \\ 4 Taradon Laboratory, Avenue Léon Champagne 2, 1480 Tubize, Belgium; \\ jp.perraudin@taradon-laboratory.com \\ * Correspondence: francoise.bafort@uliege.be
}

Received: 17 December 2018; Accepted: 3 January 2019; Published: 8 January 2019

check for updates

Featured Application: The potential applications of the lactoperoxidase system are in human health and in plant pest control. However, practical applications of this natural preservative system are still limited due to various factors that can dramatically reduce its antimicrobial activity. For an industrial application, it is fundamental to understand factors affecting lactoperoxisase activity. This study is a contribution to the increased knowledge on this issue.

\begin{abstract}
Lactoperoxidase is an enzyme that generates oxidants with antimicrobial activity in presence of a (pseudo)halogen and hydrogen peroxide, but various factors can drastically reduce the antimicrobial activity of the lactoperoxidase system. Spectroscopic, ionic chromatography, and ${ }^{13} \mathrm{C}-\mathrm{NMR}$ methods showed that the oxidants generated by lactoperoxidase are $\mathrm{OSCN}^{-}$in the presence of $\mathrm{SCN}^{-}$and $\mathrm{I}_{2}$ in the presence of $\mathrm{I}^{-}$. Neither of them, however, inhibited Penicillium expansum, one of the causal agents of fruit mold. When a mixture of $\mathrm{SCN}^{-}$and $\mathrm{I}^{-}$was used, no $\mathrm{OSCN}^{-}, \mathrm{OCN}^{-}, \mathrm{I}_{2}$, or interhalogen $\mathrm{I}_{2} \mathrm{SCN}^{-}$was produced. However, its long-term stability, $\mathrm{NH}_{2}$-oxidizing capacity, and antifungal activity against $P$. expansum argue in favor of an $\mathrm{I}^{-}$-derived oxidant. Strongly mineralized water optimized enzyme-catalyzed reactions with higher oxidant production. Storage at $4{ }^{\circ} \mathrm{C}$ resulted in long-term stability and extended antifungal activity against P. expansum. The relative iodide/thiocyanate concentrations turned out to be important, as better in vitro inhibition of Botrytis cinerea, the causal agent of apples's grey mold, was obtained with a high $\mathrm{KI}+\mathrm{KSCN}$ concentration, a $\mathrm{KI} / \mathrm{KSCN}$ ratio of 4.5 , and a $(\mathrm{KI}+\mathrm{KSCN}) / \mathrm{H}_{2} \mathrm{O}_{2}$ ratio of 1 . The nature of the substrates, their relative concentrations, the medium, and the storage temperature modifed the antifungal activity of lactoperoxidase.
\end{abstract}

Keywords: lactoperoxidase; oxidant; antifungal activity; Botrytis cinerea; Penicillium expansum 


\section{Introduction}

Plant fungal diseases are commonly controlled by applying chemical synthetic fungicides during farming or in packing houses. Alternative pest control methods are perceived as more environment-friendly and consumer-oriented, and should respond more adequately to the expectations of sustainable agriculture. However, compared to the number of active ingredients included in conventional chemical pesticides worldwide, the number of alternative methods currently licensed for disease control remains low.

Botrytis cinerea and Penicillium expansum are ubiquitous plant-pathogenic fungi whose conidia are mainly airborne, but also dispersed by water, animals, and humans [1]. B. cinerea can develop at cold storage temperatures and the disease spreads through rotted fruit contact [1]. P. expansum causes one of the most common post-harvest rots of apple [1]. Its significance has increased in recent years because it produces patulin, a mycotoxin found in rotted fruit that increases fungal virulence [2,3] and is the major cause of patulin contamination of fruit juices, compotes, and other apple-processed products [4]. In addition to Pomaceae, P. expansum is a saprophyte of other crops such as citrus fruit and cherries; patulin has been detected in bananas, peaches, apricots, grapes, grape juice, and wine. In Europe, patulin has been detected only in apple samples such as compotes and cooked fruit $(1 \mu \mathrm{g} / \mathrm{kg})$, fresh alcoholic beverages $(0.12 \mu \mathrm{g} / \mathrm{kg})$ and fruit $(0.04 \mu \mathrm{g} / \mathrm{kg})$ [4].

Lactoperoxidase (E.C.1.11.1.7; LPO) is an enzyme that occurs naturally in bovine milk and is closely related to human haem-peroxidase found in exocrine secretions such as saliva, tears, airway mucosa, or intestinal secretions. In bovine milk, LPO exerts its antibacterial activity through oxidants produced in the presence of cofactors, i.e., hydrogen peroxide $\left(\mathrm{H}_{2} \mathrm{O}_{2}\right)$ and the thiocyanate ion $\left(\mathrm{SCN}^{-}\right)$present at variable levels depending on what the cows are fed, and the iodide ion $\left(\mathrm{I}^{-}\right)$found at very low levels in bovine milk [5-8]. The oxidants derived from $\mathrm{SCN}^{-}$and $\mathrm{I}^{-}$are hypothiocyanite $\left(\mathrm{OSCN}^{-}\right)$ions and hypoiodite $\left(\mathrm{OI}^{-}\right)$ions/iodine $\left(\mathrm{I}_{2}\right)$, respectively $[9,10]$. These oxidative products have inhibitory properties against pathogenic bacteria, fungi, and viruses $[8,11-13]$. Many in vitro or in vivo applications of the LPO system have been tested. This includes the preservation of raw and pasteurized milk, storage of cosmetics, and oral care products like moisturizing gel and toothpaste. Furthermore, veterinary products, preservation of foodstuffs, or plant protection have also been tested [11,14-17]. However, practical applications of the LPO system are limited. As the catalytic reactions are complex, various factors can dramatically reduce antimicrobial activity, and the transfer from in vitro to in vivo conditions has led to inconclusive data [12,18-21]. Apart from the substrates of the LPO system, the presence of other compounds in the environment of the protein may also significantly influence its efficiency. The objective of this study is to investigate the factors that affect overall enzyme efficiency to provide information necessary for the establishment of optimal conditions for the functioning of the biological activity of the LPO system and help industrials and farmers in using this natural preservation system.

\section{Materials and Methods}

\subsection{Chemicals and Reagents}

Potassium iodide, potassium thiocyanate, hydrogen peroxide 35\%, 5-thio-nitrobenzoic acid, sodium sulfate, sodium cyanate, sodium sulfate, sodium chloride, sodium nitrate, and starch were purchased from VWR International. DL-Dithiothreitol and 3.3' $5.5^{\prime}$-tetramethylbenzidine were purchased from Sigma-Aldrich. $\mathrm{KS}^{13} \mathrm{CN}$ was obtained from Eurisotop SAS. Bentonil ${ }^{\circledR}$ was purchased from Clariant. Lactoperoxidase was purchased from Taradon Laboratory.

\subsection{Oxidant Production}

Lactoperoxidase mixed with clay was placed in a tea bag at a concentration of 50 units $/ \mathrm{mL}$ and added to $1 \mathrm{~L}$ of water containing $150 \mu \mathrm{L}$ of coagulant (Pac Sachtoklar, Brenntag N.V.). The mixture was mixed thoroughly for $1 \mathrm{~min}$. Freshly prepared $1 \mathrm{M}$ solutions of KI and/or KSCN were then added 
under gentle shaking to obtain $5.4 \mathrm{mM} \mathrm{KI}$ and/or $1.2 \mathrm{mM} \mathrm{KSCN}$ (full dose), $10.8 \mathrm{mM} \mathrm{KI}$ and/or $2.4 \mathrm{mM}$ KSCN (double-dose), and $2.7 \mathrm{mM} \mathrm{KI}$ and/or $0.6 \mathrm{mM} \mathrm{KSCN}$ (half-dose). Then, $\mathrm{H}_{2} \mathrm{O}_{2}$ was added in eight increments to obtain total concentrations of (pseudo)halogen and/or halogen. The solution was kept under shaking for $1 \mathrm{~min}$. The tea bag containing lactoperoxidase was finally removed from the solution. Other relative concentrations of substrates were tested.

\subsection{Water Mineral Characteristics}

The mineral content and $\mathrm{pH}$ of the waters used in the study are described in Table 1 . The mineral characteristics of the waters were evaluated from the dry residues, i.e., the percentages of mineral elements collected after evaporation of $1 \mathrm{~L}$ of water subjected to a temperature of $180{ }^{\circ} \mathrm{C}(\mathrm{NF}$ T90-029 August 2002, Water quality-Determination of dry residues at $105^{\circ} \mathrm{C}$ and $180{ }^{\circ} \mathrm{C}$ ). According to the NFT90-029 standard, if dry residues are $>1500 \mathrm{mg} / \mathrm{L}$, the water is said to be rich in minerals ("High mineralization": Contrex spring water from Nestlé Belgilux S.A., Bruxelles, Belgium). When it is between 500 and $1500 \mathrm{mg} / \mathrm{L}$, the water is qualified as medium mineralized ("Medium Low mineralization": tap water from Gembloux from distribution area ${ }^{\circ} 1324$ of Brye from the Société Wallonne de Distribution des Eaux (SWDE), Nivelles, Belgium; "Medium High mineralization": Vittel spring water from Nestlé Belgilux S.A., Bruxelles, Belgium). When it is between 50 and $500 \mathrm{mg} / \mathrm{L}$, the water is said to be weakly mineralized ("Low mineralization": Cristaline spring water Cristal-Roc from GIE Cristaline, France).

Table 1. Minerals content (mg/L) and $\mathrm{pH}$ of waters (values from analytical certificate analysis of water distributors).

\begin{tabular}{ccccc}
\hline $\begin{array}{c}\text { Minerals Content } \\
\mathbf{m g} / \mathbf{L}\end{array}$ & $\begin{array}{c}\text { Low Mineralization } \\
\text { Water }\end{array}$ & $\begin{array}{c}\text { Medium Low } \\
\text { Mineralization Water }\end{array}$ & $\begin{array}{c}\text { Medium High } \\
\text { Mineralization Water }\end{array}$ & $\begin{array}{c}\text { High Mineralization } \\
\text { Water }\end{array}$ \\
\hline $\mathbf{p H}$ & $\begin{array}{c}\text { Cristaline } \\
\text { Spring: Cristal-Roc }\end{array}$ & Tap Water & Vittel & Contrex \\
\hline $\mathrm{Ca}^{++}$ & 73 & 131 & 240 & 468 \\
$\mathrm{Mg}^{++}$ & 2 & 18 & 42 & 74.5 \\
$\mathrm{Na}^{+}$ & 4.5 & 32 & 5 & 9.4 \\
$\mathrm{~K}^{+}$ & 1.3 & 2.1 & 1.9 & 2.8 \\
$\mathrm{HCO}_{3}^{-}$ & 200 & 366 & 384 & 372 \\
$\mathrm{SO}_{4}^{-}$ & 20 & 84 & 400 & 2.9 \\
$\mathrm{NO}_{3}^{-}$ & $<1$ & 40 & 4.4 & 7.6 \\
$\mathrm{Cl}^{-}$ & 10 & 36 & 8 & 2078 \\
Dry residue & 223 & 550 & 1084 & 7.4 \\
\hline $\mathrm{pH}$ & 7.7 & 7.4 & 7.6 & \\
\hline
\end{tabular}

\subsection{Penicillium Expansum and Botrytis Cinerea Cultures}

Penicillium expansum (CBS 484.75) and Botrytis cinerea strain V (isolated from decayed fruit in our laboratory) were grown on a potato dextrose agar at $25^{\circ} \mathrm{C}$ in a culture chamber. After 10 days (P. expansum) or three weeks (B. cinerea) of incubation, conidia were collected by adding $9 \mathrm{~mL}$ of sterile $0.05 \%$ Tween water on the plate. Conidia were scraped off with a sterile inoculating loop and filtered through a sterilized double-layer fine cloth. The conidia concentration was adjusted using a Burker counting chamber.

\subsection{Oxidants Colorimetric Dosage}

Absorbances were recorded with an UV-visible spectrophotometer SmartSpec ${ }^{\mathrm{TM}} 3000$ from Bio-Rad Laboratories. The dosage of oxidants derived from iodide can be measured alternatively through (a) the method described in [9], which is the oxidation of SH groups of the yellow TNB (5-thio-nitrobenzoic acid). This oxidation is measured at $412 \mathrm{~nm}$ and causes discoloration of TNB that is proportional to the oxidant concentration [9]. Furthermore, (b) the method described in details in [22], which is based on the oxidation of amine $\left(\mathrm{NH}_{2}\right)$ groups of the colorless TMB 
(3.3',5.5'-tetramethylbenzidine). This oxidation is measured at $655 \mathrm{~nm}$ and causes blue coloration of oxidized-TMB that is proportional to the oxidant concentration [22].

The dosage of oxidants derived from thiocyanate can only be measured with the oxidation of SH-group of TNB ([9]), as their oxidation state is not sufficient to oxidize $\mathrm{NH}_{2}$ groups.

Iodine titration was measured by sodium thiosulfate titration [23].

\subsection{Ion Chromatography}

The determination of soluble anions was carried out using a DX-120 ion chromatograph (Dionex, Sunnyvale, CA, USA). The column was an Ion Pac AS9-HC and the pre-column an Ion Pac AG9-HC. The eluent was $9 \mathrm{mM} \mathrm{Na}_{2} \mathrm{CO}_{3} / \mathrm{NaHCO}_{3}, \mathrm{pH} 12$. The flow-rate was set to $1.0 \mathrm{~mL} \mathrm{~min}^{-1}$. All ions were detected by conductivity. Lactoperoxidase catalytic reaction were performed in MilliQ ${ }^{\circledR}$ water (Merck Chemicals S.A.) with the addition of (a) hydrogenocarbonate (584 mg/ $\mathrm{L} \mathrm{Mg}\left(\mathrm{HCO}_{3}\right)_{2}$ ) under $\mathrm{CO}_{2}$-bubbling, stirring, and warming $\left(60^{\circ} \mathrm{C}\right)$ until the solution was colorless and (b) chloride $(5 \mathrm{mg} / \mathrm{L}$ $\mathrm{Cl}^{-}$) and nitrate $\left(5 \mathrm{mg} / \mathrm{L} \mathrm{NO}_{3}{ }^{-}\right)$.

Pure potassium iodide, potassium thiocyanate, sodium cyanate, sodium sulfate, sodium chloride, and sodium nitrate were injected to assess retention times. The retention time of $\mathrm{OSCN}^{-}$was measured with a chemically prepared solution of $\mathrm{OSCN}^{-}$, according to the method described in $[9,24]$. Briefly, the lead thiocyanate $\mathrm{Pb}(\mathrm{SCN})_{2}$ was prepared; the precipitate was filtered and washed with ice water and dried in the dark under vacuum on $\mathrm{CaCl}_{2}$. Lead thiocynanate was diluted in $\mathrm{CCl}_{4}$ to obtain $0.27 \mathrm{mM} .1 \mathrm{~mL}$ of $0.14 \mathrm{mM} \mathrm{Br}_{2}$ were added in aliquots and vortexed until the $\mathrm{Br}_{2}$ solution becomes colorless. The excess lead salt was removed by centrifugation and decantation. The solution of $(\mathrm{SCN})_{2}$ was used the same day of its preparation and conserved in the dark at $4{ }^{\circ} \mathrm{C}$. The concentration of $(\mathrm{SCN})_{2}$ was measured at $296 \mathrm{~nm}$ assuming a molar extinction coefficient of $140 \mathrm{M}^{-1} \mathrm{~cm}^{-1}$. Finally, $1 \mathrm{~mL}$ of $9 \mathrm{mM}$ (SCN$)_{2}$ was added, drop by drop, to $10 \mathrm{~mL}$ of $0.1 \mathrm{M}$ cold $\mathrm{NaOH}$ and vigorously stirred using a vortex. The emulsion was separated into two phases by centrifugation at $4{ }^{\circ} \mathrm{C}$ for $10 \mathrm{~min}$ at $2500 \mathrm{rpm}$ and the $\mathrm{OSCN}^{-}$fraction was measured by oxidation of SH group at $283 \mu \mathrm{M}$ and $285 \mu \mathrm{M}$ (experiment 1), then at $323 \mu \mathrm{M}$ and $321 \mu \mathrm{M}$ (experiment 2). Overall, two independent production of chemical $\mathrm{OSCN}^{-}$were performed.

\section{7. ${ }^{13} \mathrm{C}$ Nuclear Magnetic Resonance Measurements}

${ }^{13} \mathrm{C}$ spectra were recorded at $20{ }^{\circ} \mathrm{C}$ on a Bruker AVIII HD $400 \mathrm{MHz}$ apparatus using a 5-mm broad-band probe (SmartProbeTM). Samples were placed in an 8-inch thin-walled NMR sample tube. Using direct carbon detection with proton decoupling during relaxation delay and acquisition, one-dimensional spectra were collected. The following parameters were used: a spectral window of $239 \mathrm{ppm}, 64 \mathrm{k}$ points, an acquisition time of $1.363 \mathrm{~s}$, a recycle delay of $2 \mathrm{~s}$; 2048 scans were added. Prior to Fourier-transform, the free induction decay was multiplied by a negative exponential with a line broadening of $1 \mathrm{~Hz}$. Chemical shifts were referenced relatively to DSS (4,4-dimethyl-4-silapentane-1-sulfonic acid) from Sigma. NMR samples were prepared with $540-\mu \mathrm{L}$ samples, $60 \mu \mathrm{L}$ of deuterium oxide, and $2 \mu \mathrm{L}$ of DSS $60 \mathrm{mM}$. Samples were analyzed within $12 \mathrm{~h}$ to $48 \mathrm{~h}$ after preparation and kept at $4{ }^{\circ} \mathrm{C}$ in the dark before NMR analysis. The relative intensities of the signals were analyzed and integrated using MestReNova software (version 10).

\subsection{In Vitro Antifungal Tests}

The pathogens at a final concentration of $1.10^{6}$ spores $/ \mathrm{mL}$ were cultured for five days in threefold-diluted sterile potatodextrose broth in the presence or absence (control) of an inhibiting solution, in the dark at $22{ }^{\circ} \mathrm{C}$ in ELISA plate wells, following the protocol of [25]. The controls were prepared in four replicates. The inhibiting ion solutions were prepared in eight replicates. Optical densities (ODs) at $650 \mathrm{~nm}$ were measured after $48 \mathrm{~h}$ and $120 \mathrm{~h}$ of incubation and mean ODs at $120 \mathrm{~h}$ 
were calculated to perform data analysis. The percentage of inhibition of a pathogen was calculated using the following formula [25]:

$$
\% \text { inhibition }=\left(\mathrm{OD}_{\text {control }}-\mathrm{OD}_{\text {inhibiting solution }}\right) /\left(\mathrm{OD}_{\text {control }}\right) \times 100
$$

where $\mathrm{OD}_{\text {control }}$ is the optical density of the pathogen culture after subtracting the optical density of the medium, and $\mathrm{OD}_{\text {inhibiting solution }}$ is the optical density of the inhibiting solution-treated pathogen culture after subtracting the optical density of the medium and of the inhibiting solution.

The tests were performed in two independent assays. Data were analyzed using MINITAB version 17. A one-way parametric analysis of variance (ANOVA) was performed on optical density mean values. When the analysis was statistically significant $(p<0.001)$, the means were separated using Tukey's multiple comparison test. Differences at $p<0.05$ were considered as significant.

The effect of substrate alone (KI, KSCN and $\mathrm{H}_{2} \mathrm{O}_{2}$ ) on the growth of P. expansum and B. cinerea have been performed in the reference $[11,25]$ and no inhibitory effect of substrates alone have been observed.

\section{Results}

\subsection{Influence of the Nature of the Substrates on the Oxidants and on Their Antifungal Activity}

After the $\mathrm{LPO}$ oxidoreduction of $1.2 \mathrm{mM} \mathrm{KSCN}+5.4 \mathrm{mM} \mathrm{KI}+6.6 \mathrm{mM} \mathrm{H}_{2} \mathrm{O}_{2}, 5.4 \mathrm{mM} \mathrm{KI}+5.4 \mathrm{mM}$ $\mathrm{H}_{2} \mathrm{O}_{2}$, and $1.2 \mathrm{mM} \mathrm{KSCN}+1.2 \mathrm{mM} \mathrm{H}_{2} \mathrm{O}_{2}$, as well as the removal of the enzyme, the three solutions were kept at $25{ }^{\circ} \mathrm{C}$. The oxidation of thiol groups and the biological activity against $P$. expansum was measured over 10 days. Results are presented in Table 2. No inhibition was observed with the oxidant solutions prepared from $\mathrm{SCN}^{-}$or $\mathrm{I}^{-}$. The oxidant solutions were prepared with a mixture of $\mathrm{SCN}^{-}$and $\mathrm{I}^{-}$inhibited fungal growth by 80 to $94 \%$ for 10 days. Catalytic oxidation of iodide produced stable low levels of oxidant for up to 10 days, with a yellowing after enzymatic oxidation. Iodine was titrated with sodium thiosulfate at $0.092 \mathrm{mM}$. Catalytic oxidation of thiocyanate produced high levels of oxidant on the production day and then a sharp loss after 1 day of storage, with a half-life of less than 1 day. Ion chromatography revealed the presence of $\mathrm{SCN}^{-}, \mathrm{SO}_{4}{ }^{2-}, \mathrm{OCN}^{-}$, and $\mathrm{OSCN}^{-}$(Figure 1).

Table 2. In vitro inhibition \% of $P$. expansum and $-\mathrm{SH}$ oxidant concentration $(\mu \mathrm{M})$ with various doses of substrates after oxidoreduction by lactoperoxidase and storage at $25^{\circ} \mathrm{C}$ for $0,1,2,3,5$, or 10 days. Tukey's comparison of means was applied with 95\% confidence; means that do not share a letter are significantly different; ns, not significantly different from the control. Means and s.d. of two independent experiments.

\begin{tabular}{|c|c|c|c|}
\hline & \multicolumn{3}{|c|}{ Substrate Doses } \\
\hline & $\begin{array}{c}1.2 \mathrm{mM} \mathrm{KSCN}+ \\
1.2 \mathrm{mM} \mathrm{H}_{2} \mathrm{O}_{2}\end{array}$ & $\begin{array}{c}1.2 \mathrm{mM} \mathrm{KSCN}+5.4 \mathrm{mM} \mathrm{KI} \\
+6.6 \mathrm{mM} \mathrm{H}_{2} \mathrm{O}_{2}\end{array}$ & $5.4 \mathrm{mM} \mathrm{KI}+5.4 \mathrm{mM} \mathrm{H}_{2} \mathrm{O}_{2}$ \\
\hline Storage (days) & \multicolumn{3}{|c|}{ P. expansum inhibition (\%) } \\
\hline 0 & $0 \pm 4^{\mathrm{ns}}$ & $94 \pm 3^{a}$ & $0 \pm 1^{\mathrm{ns}}$ \\
\hline 1 & - & $94 \pm 8^{a}$ & - \\
\hline 2 & - & $90 \pm 3^{a}$ & - \\
\hline 3 & - & $86 \pm 3^{a}$ & - \\
\hline 5 & - & $94 \pm 5^{a}$ & - \\
\hline \multirow[t]{2}{*}{10} & - & $80 \pm 5^{\mathrm{a}}$ & - \\
\hline & \multicolumn{3}{|c|}{ Oxidant Concentration $(\mu \mathrm{M})$} \\
\hline 0 & $359 \pm 24$ & $405 \pm 80$ & $54 \pm 6$ \\
\hline 1 & $72 \pm 9$ & $381 \pm 28$ & $55 \pm 4$ \\
\hline 2 & $17 \pm 7$ & $361 \pm 34$ & $52 \pm 4$ \\
\hline 3 & $10 \pm 5$ & $362 \pm 28$ & $45 \pm 6$ \\
\hline 5 & $0 \pm 0$ & $277 \pm 50$ & $49 \pm 11$ \\
\hline 10 & $0 \pm 0$ & $263 \pm 28$ & $52 \pm 9$ \\
\hline
\end{tabular}




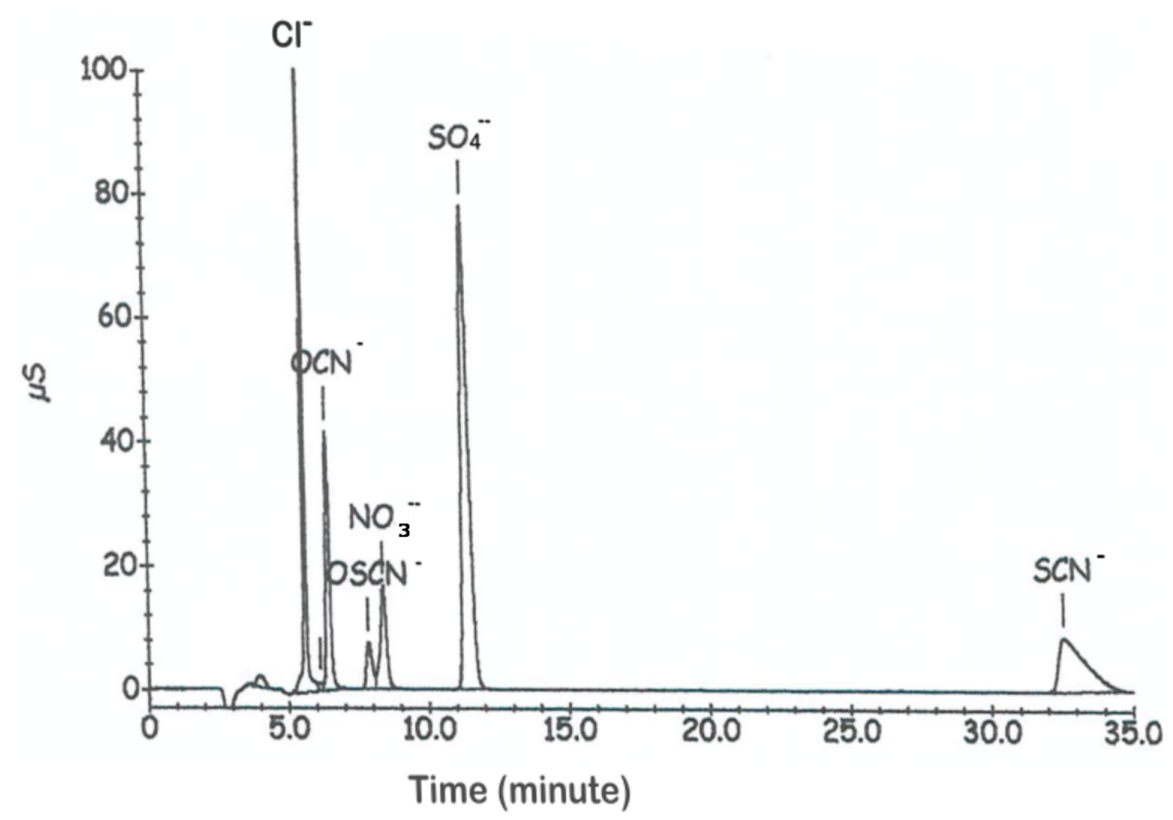

(A)

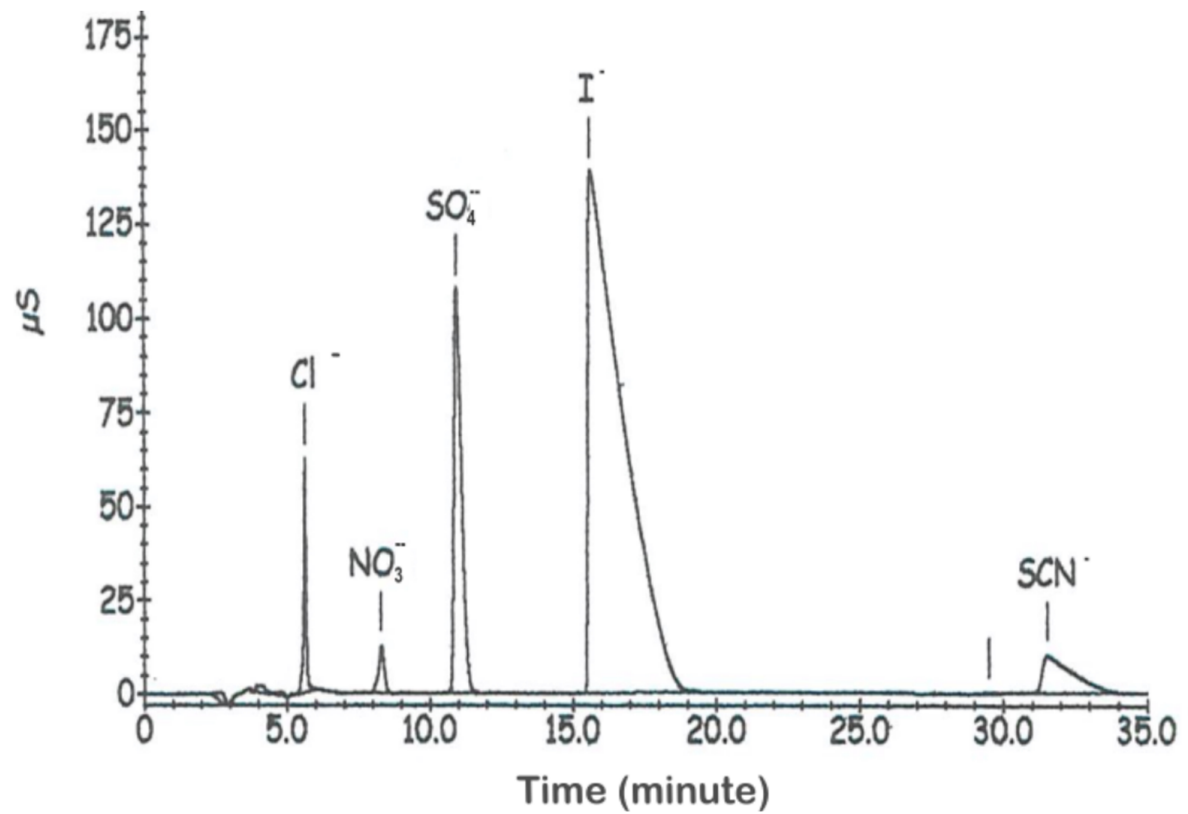

(B)

Figure 1. Ion chromatography of (A) $1.2 \mathrm{mM} \mathrm{KSCN}+1.2 \mathrm{mM} \mathrm{H}_{2} \mathrm{O}_{2}$ and (B) of $1.2 \mathrm{mM} \mathrm{KSCN}+$ $5.4 \mathrm{mM} \mathrm{KI}+6.6 \mathrm{mM} \mathrm{H}_{2} \mathrm{O}_{2}$ after oxidoreduction by lactoperoxidase in Milli- ${ }^{\circledR}$ water. Representative spectra of two independent experiments is given.

Catalytic oxidation of the iodide-thiocyanate mixture produced a colorless solution containing stable and highly dosed oxidant with a shelf-life of more than 10 days (Table 2). Iodine titration was performed; no iodine was measured. Ion chromatography of the $\mathrm{SCN}^{-}$- and $\mathrm{I}^{-}$-derived solution detected $\mathrm{I}^{-}, \mathrm{SCN}^{-}$, and $\mathrm{SO}_{4}{ }^{2-}$, but did not detect any $\mathrm{OSCN}^{-}, \mathrm{OCN}^{-}$, or $\mathrm{OI}^{-}$(Figure 1).

${ }^{13} \mathrm{C}$ NMR was performed on two solutions: $1.2 \mathrm{mM} \mathrm{KS}{ }^{13} \mathrm{CN}+1.2 \mathrm{mM} \mathrm{H}_{2} \mathrm{O}_{2}$ and $1.2 \mathrm{mM} \mathrm{KS}{ }^{13} \mathrm{CN}$ $+5.4 \mathrm{mM} \mathrm{KI}+6.6 \mathrm{mM} \mathrm{H}_{2} \mathrm{O}_{2}$ (Figure 2). It confirmed the presence of $\mathrm{OCN}^{-}$and $\mathrm{OSCN}^{-}$in the $\mathrm{SCN}^{-}$-oxidized solution [26] and the absence of $\mathrm{OSCN}^{-}, \mathrm{OCN}^{-}$or interpseudohalogen molecules, such as $\mathrm{ICN}, \mathrm{I}(\mathrm{SCN})_{2}{ }^{-}$, and $\mathrm{I}_{2} \mathrm{SCN}^{-}$in the $\mathrm{SCN}^{-}$- and $\mathrm{I}^{-}$-oxidized solutions [25]. 

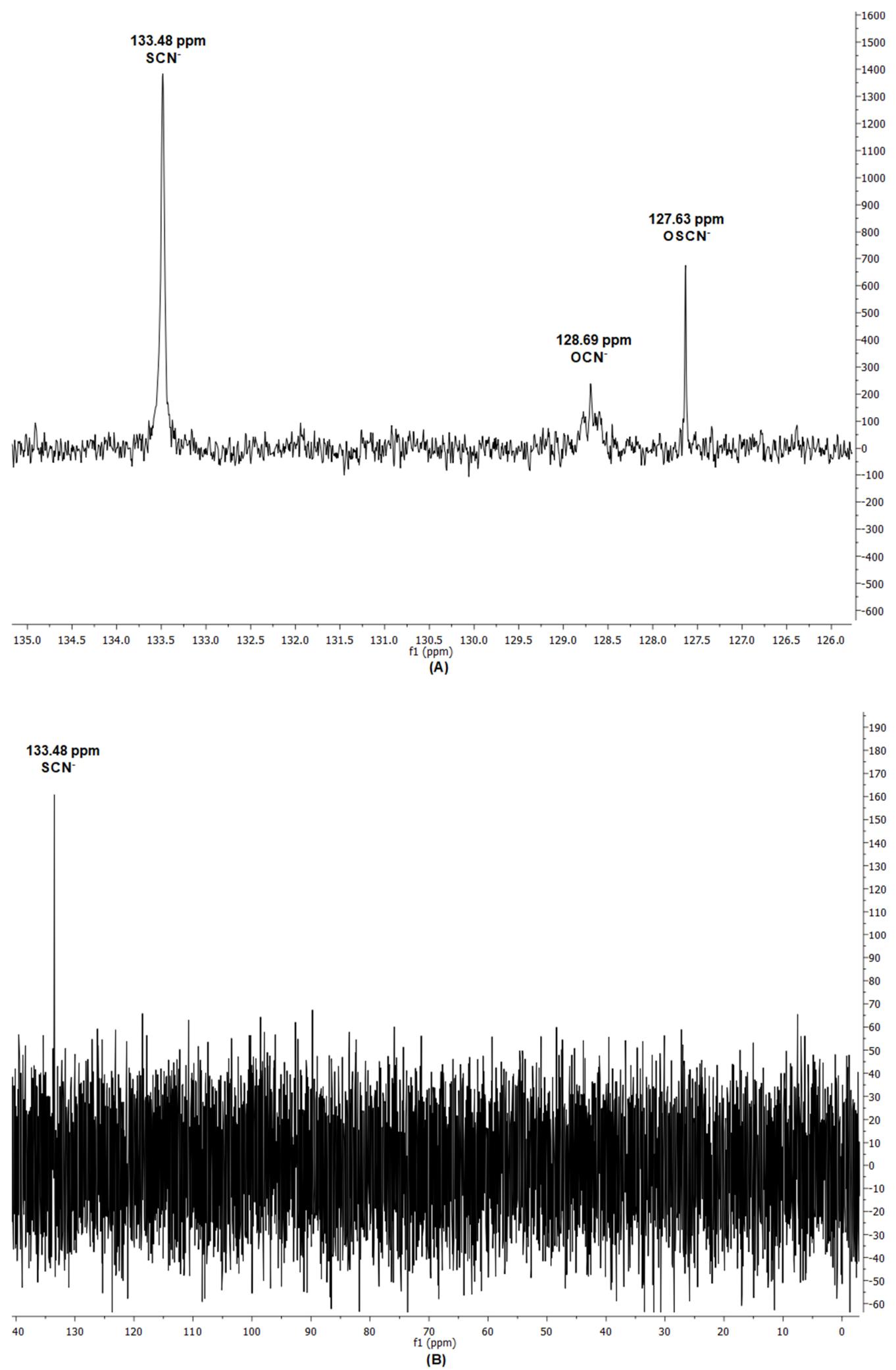

Figure 2. ${ }^{13} \mathrm{C}$ NMR chemical shift of (A) $1.2 \mathrm{mM} \mathrm{KS}^{13} \mathrm{CN}+1.2 \mathrm{mM} \mathrm{H}_{2} \mathrm{O}_{2}$ or (B) $1.2 \mathrm{mM} \mathrm{KS}{ }^{13} \mathrm{CN}+$ $5.4 \mathrm{mM} \mathrm{KI}+6.6 \mathrm{mM} \mathrm{H}_{2} \mathrm{O}_{2}$ after lactoperoxidase oxidoreduction in tap water. Representative spectra of two independent experiments are given. 


\subsection{Influence of Water Mineralization on Oxidant Production}

We used four waters with various mineralization levels (low, medium low, medium high, or high) to carry out the oxidoreduction of $1.2 \mathrm{mM} \mathrm{KSCN}+5.4 \mathrm{mM} \mathrm{KI}+6.6 \mathrm{mM} \mathrm{H}_{2} \mathrm{O}_{2}$ (full dose), $0.6 \mathrm{mM}$ $\mathrm{KSCN}+2.7 \mathrm{mM} \mathrm{KI}+3.3 \mathrm{mM} \mathrm{H}_{2} \mathrm{O}_{2}$ (half dose), and $2.4 \mathrm{mM} \mathrm{KSCN}+10.8 \mathrm{mM} \mathrm{KI}+13.2 \mathrm{mM} \mathrm{H}_{2} \mathrm{O}_{2}$ (double dose) by $50 \mathrm{U} / \mathrm{mL}$ of LPO (Table 3). In the full dose, oxidant production was favored by water mineralization, i.e., lower mineralization gave the lowest oxidant production and higher mineralization gave the highest oxidant concentration. The effect of mineralization on oxidant production was less pronounced with half-doses of substrates. Conversely, it was more pronounced with double-dosed substrates: high mineralization induced a 1.78-fold increase of oxidant production in regards to the lowest mineralized water.

Table 3. Oxidant concentration measured as $-\mathrm{NH}_{2}$ oxidation $(\mu \mathrm{M})$ after $\mathrm{LPO}$ oxidoreduction of $2.7 \mathrm{mM}$ $\mathrm{KI}+0.6 \mathrm{mM} \mathrm{KSCN}+3.3 \mathrm{mM} \mathrm{H}_{2} \mathrm{O}_{2}$ (half-dose); $5.4 \mathrm{mM} \mathrm{KI}+1.2 \mathrm{mM} \mathrm{KSCN}+6.6 \mathrm{mM} \mathrm{H}_{2} \mathrm{O}_{2}$ (full dose) and $10.8 \mathrm{mM} \mathrm{KI}+2.4 \mathrm{mM} \mathrm{KSCN}+13.2 \mathrm{mM} \mathrm{H}_{2} \mathrm{O}_{2}$ (double-dose) in low- to high-mineralized waters. Means and s.d. of two independent experiments are given.

\begin{tabular}{ccccc}
\hline & \multicolumn{4}{c}{ Water Mineralization } \\
\cline { 2 - 5 } & Low & Medium Low & Medium High & High \\
\hline Substrate Doses & \multicolumn{4}{c}{ Oxidant Concentration $(\mu \mathrm{M})$} \\
\hline Half-dose & $291 \pm 20$ & $254 \pm 44$ & $235 \pm 32$ & $256 \pm 16$ \\
Full-dose & $383 \pm 25$ & $407 \pm 17$ & $503 \pm 33$ & $538 \pm 42$ \\
Double-dose & $546 \pm 24$ & $563 \pm 18$ & $785 \pm 29$ & $974 \pm 49$ \\
\hline
\end{tabular}

\subsection{Influence of the Storage Temperature on Oxidant Stability and Antifungal Activity}

The influence of the storage temperature is showed in Figure 3. Storage at $4{ }^{\circ} \mathrm{C}$ noticeably increased the shelf-life of the oxidant, whatever the substrate dose and the initial oxidant concentration. The solutions prepared with double-dose substrate concentrations contained higher initial oxidant doses, but also underwent a higher degradation rate. Full-dose solutions prepared with high mineralized waters (Medium High and High) and double-dose solutions prepared with low mineralized waters (Low and Medium low) showed similar initial oxidant doses of around $500 \mu \mathrm{M}$. However, the shelf-life at $25{ }^{\circ} \mathrm{C}$ was around 90 days for the full dose and 25 days for the double dose. At $4{ }^{\circ} \mathrm{C}$, it was more than 360 days for the full dose and 120 days for the double dose.

The biological activity of the oxidant was clearly related to its dose (Tables 4-6), which implies that the rate of oxidant degradation affects biological activity duration. The remanence of biological activity was influenced by the storage temperature and the initial oxidant dose. Cold storage of the oxidant and reduced amounts of substrates (half and full doses) prolonged the biological activity of the oxidant. The storage temperature also seemed to affect the minimum inhibitory dose, with enhanced efficiency of the oxidants kept at $4{ }^{\circ} \mathrm{C}$. At $25^{\circ} \mathrm{C}$, the oxidant dose necessary for biological activity was around $205 \mu \mathrm{M}$ for the half dose, $157 \mu \mathrm{M}$ for the full dose, and $219 \mu \mathrm{M}$ for the double dose. At $4{ }^{\circ} \mathrm{C}$, the oxidant dose necessary for biological activity was around $150 \mu \mathrm{M}$ for the half dose, $111 \mu \mathrm{M}$ for the full dose, and $172 \mu \mathrm{M}$ for the double dose. 
$4^{\circ} \mathrm{C}$

(A)

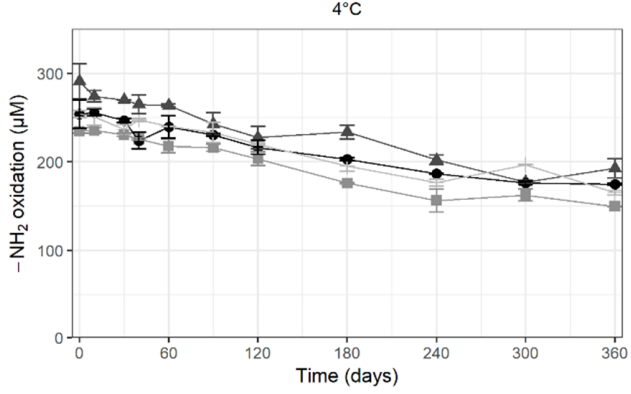

$4^{\circ} \mathrm{C}$

(B)

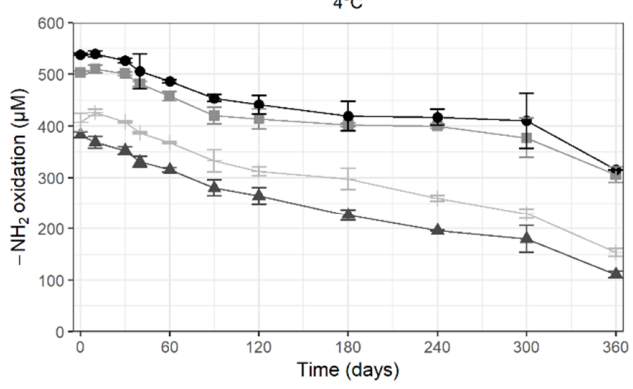

$4^{\circ} \mathrm{C}$

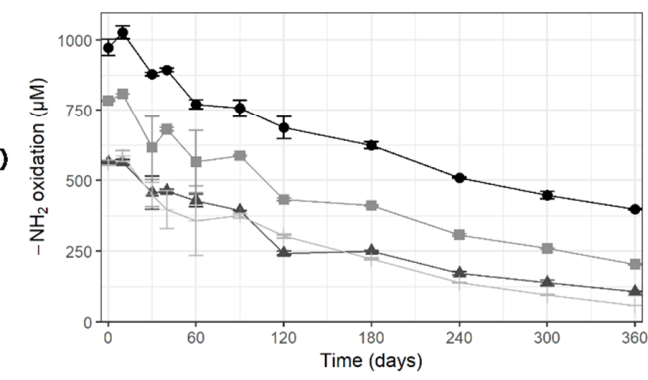

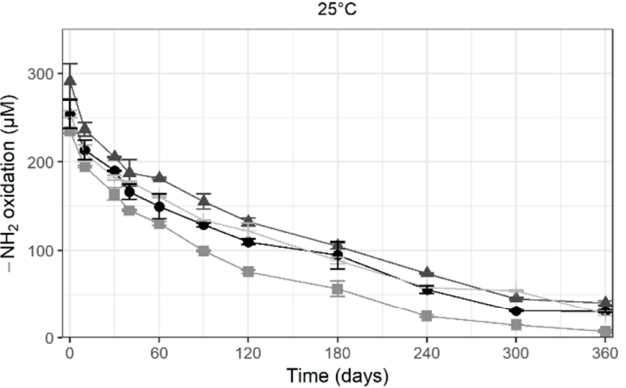

$25^{\circ} \mathrm{C}$

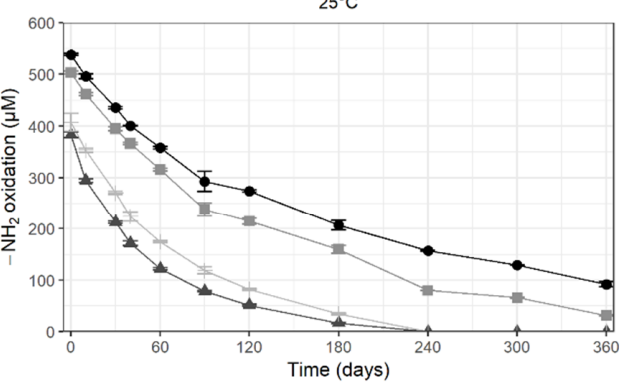

$25^{\circ} \mathrm{C}$

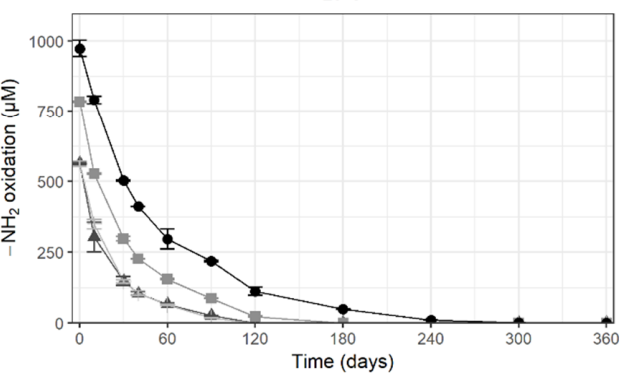

Water Mineralization - High - Low - MedHigh + MedLow

Figure 3. Oxidant concentration expressed in $-\mathrm{NH}_{2}$ oxidation $(\mu \mathrm{M})$ of $(\mathbf{A})$ (half-dose): $2.7 \mathrm{mM} \mathrm{KI}$ + $0.6 \mathrm{mM} \mathrm{KSCN}+3.3 \mathrm{mM} \mathrm{H}_{2} \mathrm{O}_{2}$; (B) (full-dose): of $5.4 \mathrm{mM} \mathrm{KI}+1.2 \mathrm{mM} \mathrm{KSCN}+6.6 \mathrm{mM} \mathrm{H}_{2} \mathrm{O}_{2}$; (C) (double-dose): $10.8 \mathrm{mM} \mathrm{KI}+2.4 \mathrm{mM} \mathrm{KSCN}+13.2 \mathrm{mM} \mathrm{H}_{2} \mathrm{O}_{2}$ in differentially mineralized (low, medium low, medium high, and high) waters after lactoperoxidase oxidation and over 360 days of storage at $4{ }^{\circ} \mathrm{C}$ or $25^{\circ} \mathrm{C}$. Means and s.d. of two independent experiments are given. MedLow: Medium low; MedHigh: Medium High.

Table 4. Percentage of inhibition of P. expansum growth by half-dose solutions $(2.7 \mathrm{mM} \mathrm{KI}+0.6 \mathrm{mM}$ $\mathrm{KSCN}+3.3 \mathrm{mM} \mathrm{H}_{2} \mathrm{O}_{2}$ ) after lactoperoxidase oxidoreduction in low- to high-mineralized waters and storage at $25{ }^{\circ} \mathrm{C}$ or $4{ }^{\circ} \mathrm{C}$ for 360 days. Tukey's comparison of means was applied with $95 \%$ confidence; means that do not share a letter are significantly different; ns, not significantly different from the control. Temp.: storage temperature. Means and s.d. of the two independent experiments are given.

\begin{tabular}{ccccccc}
\hline & & \multicolumn{5}{c}{ Storage Duration (Days) } \\
\cline { 3 - 7 } & & $\mathbf{0}$ & $\mathbf{3 0}$ & $\mathbf{9 0}$ & $\mathbf{2 4 0}$ & $\mathbf{3 6 0}$ \\
\hline \multirow{2}{*}{ Temp. } & Water & \multicolumn{5}{c}{ P. expansum Inhibition (\%) } \\
& Mineralization & \multicolumn{5}{c}{} \\
\hline \multirow{3}{*}{$25{ }^{\circ} \mathbf{C}$} & Low & $91 \pm 5^{\mathrm{b}}$ & $81 \pm 4^{\mathrm{a}}$ & $26 \pm 4^{\mathrm{c}}$ & $0 \pm 6^{\mathrm{ns}}$ & $4 \pm 2^{\mathrm{ns}}$ \\
& Medium Low & $88 \pm 7^{\mathrm{b}}$ & $24 \pm 10^{\mathrm{ns}}$ & $0 \pm 2^{\mathrm{ns}}$ & $0 \pm 2^{\mathrm{ns}}$ & $0 \pm 4^{\mathrm{ns}}$ \\
& Medium High & $92 \pm 2^{\mathrm{b}}$ & $0 \pm 1^{\mathrm{ns}}$ & $5 \pm 5^{\mathrm{ns}}$ & $0 \pm 4^{\mathrm{ns}}$ & $7 \pm 7^{\mathrm{ns}}$ \\
& High & $89 \pm 3^{\mathrm{b}}$ & $0 \pm 0^{\mathrm{ns}}$ & $0 \pm 1^{\mathrm{ns}}$ & $3 \pm 6^{\mathrm{ns}}$ & $0 \pm 5^{\mathrm{ns}}$ \\
\hline \multirow{3}{*}{$\mathbf{4}^{\circ} \mathbf{C}$} & Low & $100 \pm 0^{\mathrm{a}}$ & $73 \pm 8^{\mathrm{a}}$ & $95 \pm 3^{\mathrm{a}}$ & $95 \pm 3^{\mathrm{a}}$ & $95 \pm \pm^{\mathrm{a}}$ \\
& Medium Low & $99 \pm 1^{\mathrm{a}}$ & $89 \pm 5^{\mathrm{a}}$ & $91 \pm 2^{\mathrm{a}}$ & $96 \pm 4^{\mathrm{a}}$ & $92 \pm{ }^{\mathrm{a}}$ \\
& Medium High & $100 \pm 0^{\mathrm{a}}$ & $73 \pm 7^{\mathrm{a}}$ & $53 \pm 3^{\mathrm{bc}}$ & $61 \pm{ }^{\mathrm{c}}$ & $90 \pm \pm^{\mathrm{a}}$ \\
& High & $100 \pm 0^{\mathrm{a}}$ & $75 \pm 4^{\mathrm{a}}$ & $63 \pm 11^{\mathrm{b}}$ & $85 \pm{ }^{\mathrm{b}}$ & $90 \pm{ }^{\mathrm{a}}$ \\
\hline
\end{tabular}


Table 5. Percentage of inhibition of P. expansum growth by full-dose solutions ( $5.4 \mathrm{mM} \mathrm{KI}+1.2 \mathrm{mM}$ $\mathrm{KSCN}+6.6 \mathrm{mM} \mathrm{H}_{2} \mathrm{O}_{2}$ ) after lactoperoxidase oxidoreduction in low- to high-mineralized waters and storage at $25^{\circ} \mathrm{C}$ or $4{ }^{\circ} \mathrm{C}$ for 360 days. Tukey's comparison of means was applied with $95 \%$ confidence; means that do not share a letter are significantly different; ns, not significantly different from the control. Temp.: storage temperature. Water mineral.: water mineralization. Means and s.d. of two independent experiments are given.

\begin{tabular}{ccccccccc}
\hline & \multicolumn{7}{c}{ Storage Duration (Days) } \\
\cline { 3 - 9 } & & $\mathbf{0}$ & $\mathbf{3 0}$ & $\mathbf{9 0}$ & $\mathbf{1 5 0}$ & $\mathbf{2 4 0}$ & $\mathbf{3 0 0}$ & $\mathbf{3 6 0}$ \\
\hline Temp. & Water Mineral. & \multicolumn{7}{c}{ P.expansum Inhibition (\%) } \\
\hline \multirow{3}{*}{$\mathbf{2 5}^{\circ} \mathbf{C}$} & Low & $89 \pm 2^{\mathrm{b}}$ & $98 \pm 1^{\mathrm{ab}}$ & $10 \pm 7^{\mathrm{ns}}$ & $14 \pm 10^{\mathrm{ns}}$ & $17 \pm 11^{\mathrm{ns}}$ & $6 \pm 5^{\mathrm{ns}}$ & $2 \pm 1^{\mathrm{ns}}$ \\
& Medium Low & $89 \pm 1^{\mathrm{b}}$ & $96 \pm 2^{\mathrm{ab}}$ & $8 \pm 5^{\mathrm{ns}}$ & $3 \pm 2^{\mathrm{ns}}$ & $15 \pm 8^{\mathrm{ns}}$ & $2 \pm 1^{\mathrm{ns}}$ & $4 \pm 3^{\mathrm{ns}}$ \\
& Medium High & $92 \pm 0^{\mathrm{ab}}$ & $95 \pm 4^{\mathrm{ab}}$ & $90 \pm 4^{\mathrm{a}}$ & $85 \pm 4^{\mathrm{a}}$ & $2 \pm 1^{\mathrm{ns}}$ & $0 \pm 0^{\mathrm{ns}}$ & $5 \pm 4^{\mathrm{ns}}$ \\
& High & $95 \pm 0^{\mathrm{a}}$ & $91 \pm 5^{\mathrm{a}}$ & $93 \pm 5^{\mathrm{a}}$ & $86 \pm 5^{\mathrm{ab}}$ & $89 \pm 6^{\mathrm{a}}$ & $1 \pm 1^{\mathrm{ns}}$ & $1 \pm 1^{\mathrm{ns}}$ \\
\hline \multirow{4}{*}{$\mathbf{4}^{\circ} \mathbf{C}$} & Low & $90 \pm 5^{\mathrm{ab}}$ & $97 \pm 2^{\mathrm{ab}}$ & $100 \pm 0^{\mathrm{a}}$ & $98 \pm 3^{\mathrm{b}}$ & $92 \pm 5^{\mathrm{a}}$ & $93 \pm 4^{\mathrm{a}}$ & $94 \pm 5^{\mathrm{a}}$ \\
& Medium Low & $90 \pm 1^{\mathrm{ab}}$ & $99 \pm 1^{\mathrm{b}}$ & $92 \pm 3^{\mathrm{a}}$ & $89 \pm 5^{\mathrm{ab}}$ & $89 \pm 5^{\mathrm{a}}$ & $92 \pm 1^{\mathrm{a}}$ & $92 \pm 6^{\mathrm{a}}$ \\
& Medium High & $91 \pm 3^{\mathrm{ab}}$ & $93 \pm 3^{\mathrm{ab}}$ & $87 \pm 0^{\mathrm{a}}$ & $83 \pm 5^{\mathrm{a}}$ & $89 \pm 4^{\mathrm{a}}$ & $92 \pm 0^{\mathrm{a}}$ & $91 \pm 4^{\mathrm{a}}$ \\
& High & $94 \pm 1^{\mathrm{ab}}$ & $94 \pm 3^{\mathrm{ab}}$ & $88 \pm 2^{\mathrm{a}}$ & $85 \pm 6^{\mathrm{a}}$ & $90 \pm 6^{\mathrm{a}}$ & $92 \pm 3^{\mathrm{a}}$ & $9^{ \pm} \pm 5^{\mathrm{a}}$ \\
\hline
\end{tabular}

Table 6. Percentage of inhibition of P. expansum growth by double-dose solutions $(10.8 \mathrm{mM} \mathrm{KI}+2.4 \mathrm{mM}$ $\mathrm{KSCN}+13.2 \mathrm{mM} \mathrm{H}_{2} \mathrm{O}_{2}$ ) after lactoperoxidase oxidoreduction in low- to high-mineralized waters and storage at $25^{\circ} \mathrm{C}$ or $4{ }^{\circ} \mathrm{C}$ for 360 days. Tukey's comparison of means was applied with $95 \%$ confidence; means that do not share a letter are significantly different; ns, not significantly different from the control. Temp.: storage temperature; Water mineral.: water mineralization; M. Low: medium low; M. High: medium high. Means and s.d. of two independent experiments are given.

\begin{tabular}{|c|c|c|c|c|c|c|c|c|c|}
\hline & & \multicolumn{8}{|c|}{ Storage Duration (Days) } \\
\hline & & 0 & 30 & 90 & 120 & 180 & 240 & 300 & 360 \\
\hline Temp. & Water Mineral. & \multicolumn{8}{|c|}{ P. expansum Inhibition (\%) } \\
\hline \multirow{4}{*}{$25^{\circ} \mathrm{C}$} & Low & $94 \pm 3^{a}$ & $14 \pm 10^{\mathrm{ns}}$ & $0 \pm 0^{\text {ns }}$ & $10 \pm 4^{\mathrm{ns}}$ & $0 \pm 1^{\mathrm{ns}}$ & $0 \pm 0^{\mathrm{ns}}$ & $2 \pm 1^{\mathrm{ns}}$ & $0 \pm 0^{\mathrm{ns}}$ \\
\hline & M. Low & $93 \pm 4^{\mathrm{a}}$ & $0 \pm 0^{\mathrm{ns}}$ & $0 \pm 0$ ns & $8 \pm 2^{\mathrm{ns}}$ & $6 \pm 2^{\mathrm{ns}}$ & $2 \pm 1^{\mathrm{ns}}$ & $5 \pm 3^{\mathrm{ns}}$ & $3 \pm 2^{\mathrm{ns}}$ \\
\hline & M. High & $91 \pm 2^{\mathrm{a}}$ & $88 \pm 8^{a}$ & $0 \pm 0^{\text {ns }}$ & $4 \pm 4^{\mathrm{ns}}$ & $5 \pm 3^{\text {ns }}$ & $9 \pm 4^{\mathrm{ns}}$ & $4 \pm 2^{\mathrm{ns}}$ & $2 \pm 1^{\text {ns }}$ \\
\hline & High & $91 \pm 4^{\mathrm{a}}$ & $87 \pm 5^{\mathrm{a}}$ & $88 \pm 1^{\text {a }}$ & $0 \pm 0^{\mathrm{ns}}$ & $0 \pm 0^{\mathrm{ns}}$ & $3 \pm 3^{\mathrm{ns}}$ & $0 \pm 1^{\mathrm{ns}}$ & $0 \pm 0$ ns \\
\hline \multirow{4}{*}{$4^{\circ} \mathrm{C}$} & Low & $99 \pm 1^{b}$ & $88 \pm 4^{\mathrm{a}}$ & $90 \pm 0^{\mathrm{a}}$ & $91 \pm 1^{\mathrm{a}}$ & $88 \pm 3^{a}$ & $94 \pm 1^{a}$ & $31 \pm 10^{\mathrm{a}}$ & $59 \pm 5^{a}$ \\
\hline & M. Low & $98 \pm 2^{b}$ & $89 \pm 4^{a}$ & $89 \pm 3^{\mathrm{a}}$ & $91 \pm 2^{a}$ & $87 \pm 2^{a}$ & $6 \pm 3^{\mathrm{ns}}$ & $1 \pm 1^{\mathrm{ns}}$ & $10 \pm 3^{\mathrm{ns}}$ \\
\hline & M. High & $99 \pm 0 \mathrm{~b}$ & $86 \pm 3^{a}$ & $88 \pm 3^{a}$ & $92 \pm 2^{a}$ & $85 \pm 4^{\mathrm{a}}$ & $92 \pm 2^{a}$ & $90 \pm 5^{b}$ & $89 \pm 4^{b}$ \\
\hline & High & $98 \pm 2^{b}$ & $90 \pm 6^{\mathrm{a}}$ & $88 \pm 4^{\mathrm{a}}$ & $90 \pm 3^{a}$ & $84 \pm 3^{a}$ & $91 \pm 0^{\mathrm{a}}$ & $97 \pm 4^{b}$ & $92 \pm 5^{b}$ \\
\hline
\end{tabular}

\subsection{Influence of the Relative Substrate Concentrations on Oxidant Levels and Antifungal Activity}

\subsubsection{Influence of the Relative Substrate Concentrations on Oxidant Levels}

We classified the relative iodide/thiocyanate concentrations in three categories: <1 (Figure 4), $=1$ (Figure 5) and $>1$ (Figure 6), and measured the influence of each ratio through the level of produced oxidant. When thiocyanate is the major substrate present in the media $(\mathrm{KI} / \mathrm{KSCN}$ ratio $<1 ;$ Figure 4$)$, oxidant production stayed low unless thiocyanate was added at a high concentration (10 mM KSCN). The capacity to oxidize the $-\mathrm{NH}_{2}$ group remained low, with a maximum concentration at $25 \mu \mathrm{M}$, even with a high iodide concentration. As the $\mathrm{NH}_{2}$-dosage was very low and clearly different from $\mathrm{SH}$-dosage, it can be hypothesized that $\mathrm{SH}$-dosage is predominantly due to oxidized thiocyanate. However, even with $10 \mathrm{mM} \mathrm{KSCN}$, the SH-dosage reached only $250 \mu \mathrm{M}$, which is low when compared with $350 \mu \mathrm{M} \mathrm{OSCN}^{-}$produced with $1.2 \mathrm{mM} \mathrm{KSCN}$ as the sole substrate (Table 2). The addition of iodide act like an inhibitor of $\mathrm{OSCN}^{-}$production. Three ratios showed this clearly: (i) $1.2 \mathrm{mM}$ $\mathrm{KI}+5.4 \mathrm{mM} \mathrm{KSCN}$, (ii) $1.2 \mathrm{mM} \mathrm{KI}+4.05 \mathrm{mM} \mathrm{KSCN}$, and (iii) $1.2 \mathrm{mM} \mathrm{KI}+1.35 \mathrm{mM} \mathrm{KSCN}$, which represent $4.5,3.37$, and 1.12 , respectively, more thiocyanate than iodide, as well as where $\mathrm{OSCN}^{-}$ production increased with thiocyanate quantity and $\mathrm{NH}_{2}$-dosage increased with iodide concentration relatively to thiocyanate. The lactoperoxidase system that used a mixture of iodide and thiocyanate in 
which thiocyanate is the major substrate represent a less-effective way of oxidants production and a substrate-expensive way of use of the LPO-system.

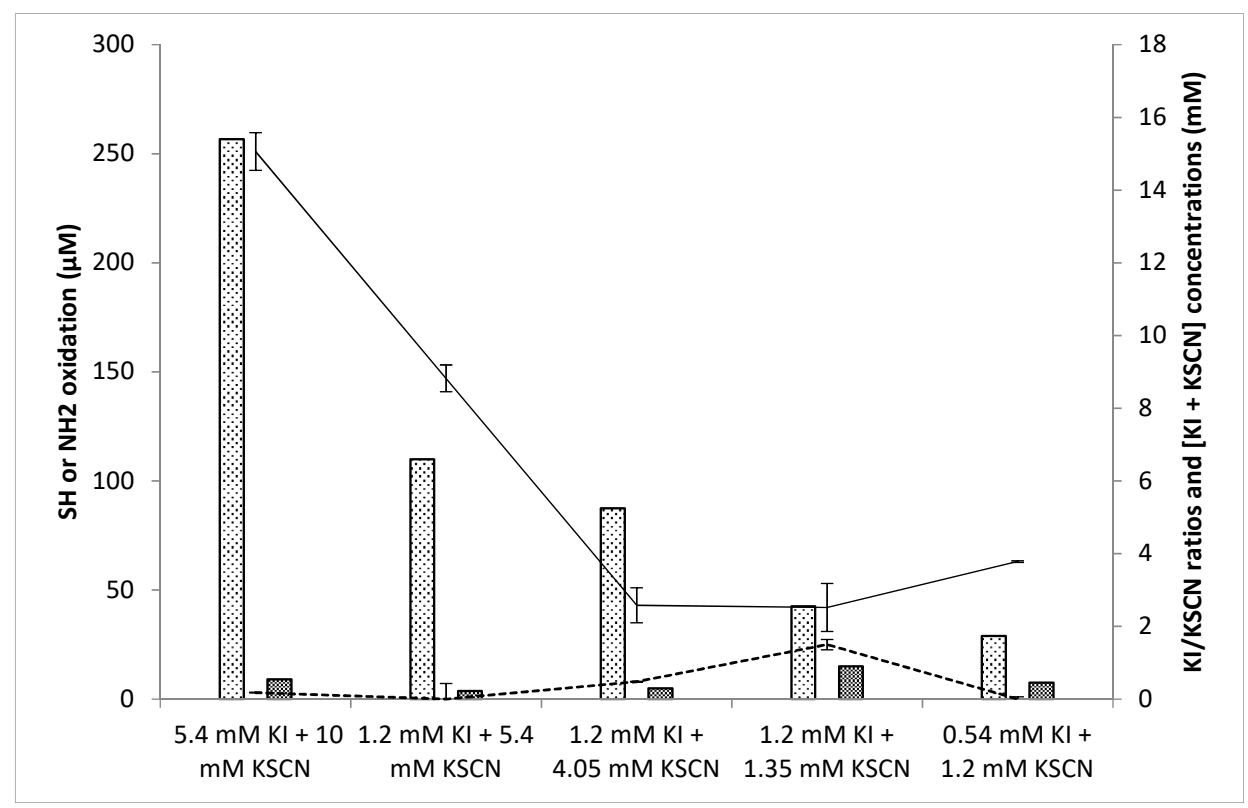

Figure 4. $\mathrm{KI} / \mathrm{KSCN}$ ratio $<1$. Oxidation levels of $-\mathrm{SH}$ (plain line) and $-\mathrm{NH}_{2}$ (dashed line) $(\mu \mathrm{M})$, total pseudo-halogen concentrations (light-colored bars) (mM), and KI/KSCN ratios (dark-colored bars) $(\mathrm{mM})$ of various doses of $(\mathrm{KI}+\mathrm{KSCN})$ after lactoperoxidase oxidoreduction in tap water. Means and s.d. of the two independent experiments are given.

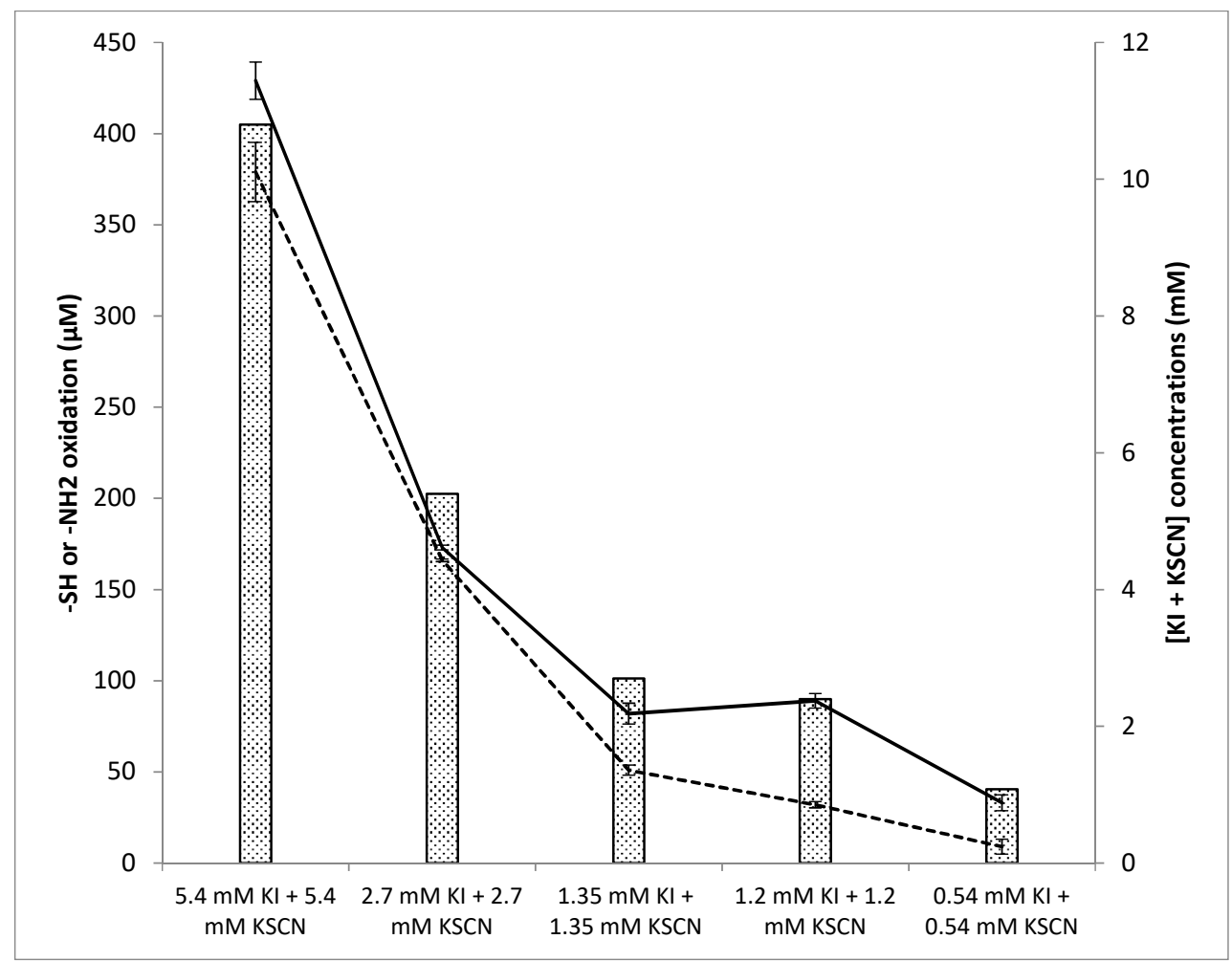

Figure 5. $\mathrm{KI} / \mathrm{KSCN}$ ratio $=1$. Oxidation levels of $-\mathrm{SH}$ (plain line) and $-\mathrm{NH}_{2}$ (dashed line) $(\mu \mathrm{M})$, and total pseudo-halogen concentrations (light bars) $(\mathrm{mM})$ of various doses of (KI $+\mathrm{KSCN})$ after lactoperoxidase oxidoreduction in tap water. Means and s.d. of the two independent experiments are given. 


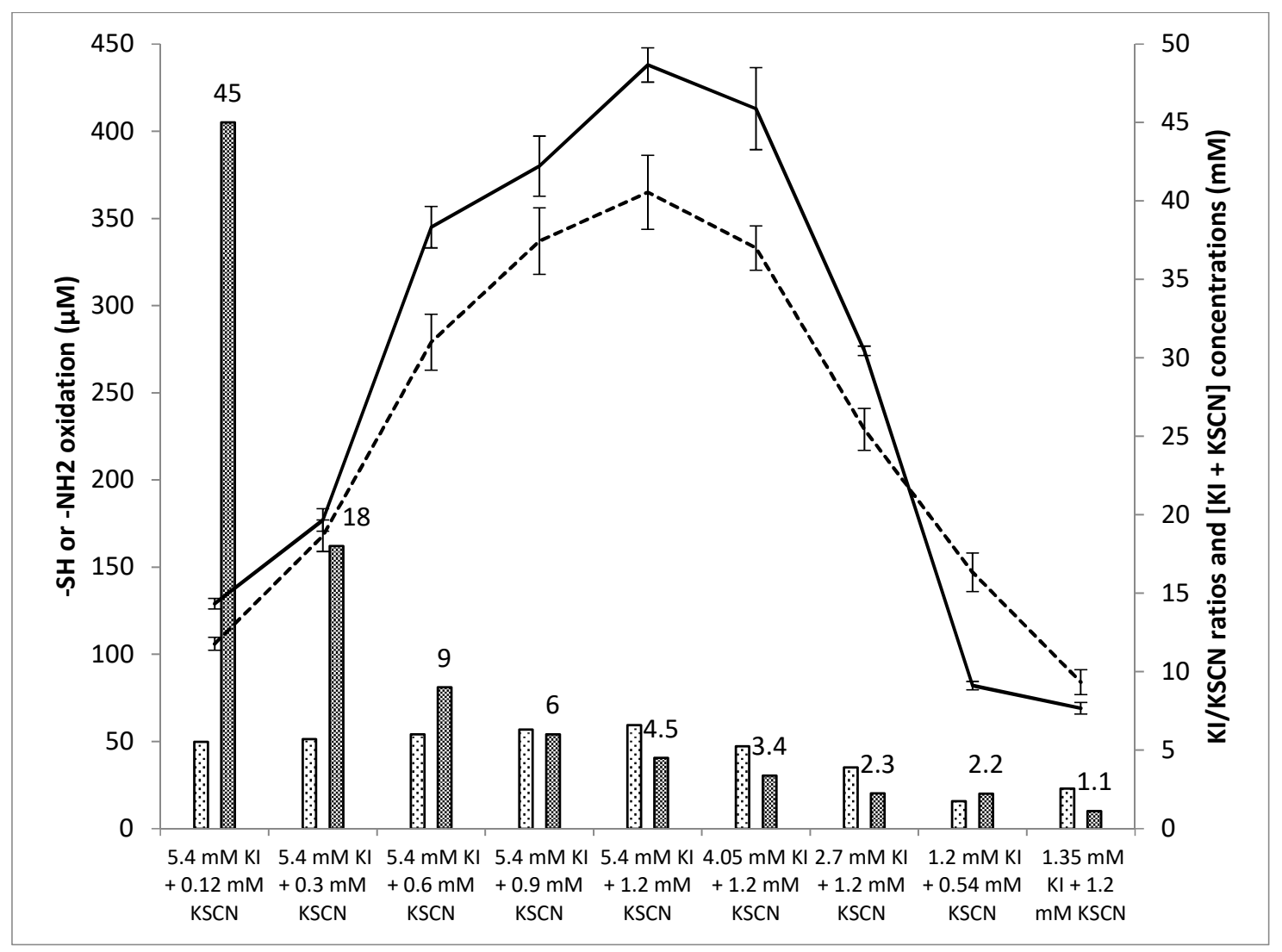

Figure 6. KI/KSCN ratio $>1$. Oxidation levels of $-\mathrm{SH}$ (plain line) and $-\mathrm{NH}_{2}$ (dashed line) $(\mu \mathrm{M})$, total pseudo-halogen concentrations (light-colored bars) (mM), and KI/KSCN ratios (dark-colored bars) $(\mathrm{mM})$ of various doses of $(\mathrm{KI}+\mathrm{KSCN})$ after lactoperoxidase oxidoreduction in tap water. Means and s.d. of the two independent experiments are given.

When the same amount of thiocyanate and iodide are added in the media $(\mathrm{KI} / \mathrm{KSCN}$ ratio $=1$; Figure 5), the enzyme is able to produced high doses of oxidants if the total amount of substrate added are high. The SH-dosage is relatively close to the $\mathrm{NH}_{2}$-dosage, so that it can be hypothesized that oxidant are mainly represented by iodide-oxidized oxidant. The oxidation of iodide seems to be more effective when both substrates increased. However, the use of equal amount of iodide and thiocyanate are less-effective in oxidants production, especially with regards to the total quantity of substrates added $(10.8 \mathrm{mM})$ that reached about $400 \mu \mathrm{M}$ oxidant when compared with total substrate of $6.6 \mathrm{mM}$ (5.4 mM KI $+1.2 \mathrm{mM} \mathrm{KSCN}$ ) and the same amount of $400 \mu \mathrm{M}$ oxidants produced (Table 2).

When more iodide is added relative to thiocyanate (KI/KSCN ratio $>1$; Figure 6), the oxidant production curve was bell-shaped, with an optimal ratio around 4.5, and a less favorable ratio above 9 or below 2.5. If the ratio moved closer to 1 , the oxidant production decreased, as if the ratio increased above 9 . A ratio above 9 means that thiocyanate dropped, and could mean that oxidation of a precise level of thiocyanate is essential for an optimal level of iodide-derived oxidant production.

\subsubsection{Influence of the Substrate Concentrations on Antifungal Activity}

We measured the influence of the relative substrate concentrations on B. cinerea inhibition (Table 7). We tested $14 \mathrm{KI} / \mathrm{KSCN} / \mathrm{H}_{2} \mathrm{O}_{2}$ ratios at 3 dilutions each. The oxidant induced better inhibition with (i) high $\mathrm{KI}+\mathrm{KSCN}$ concentrations, (ii) a $\mathrm{KI} / \mathrm{KSCN}$ ratio of 4.5 , and (iii) a $(\mathrm{KI}+\mathrm{KSCN}) / \mathrm{H}_{2} \mathrm{O}_{2}$ ratio of 1 . Increased dilution combined with lower $(\mathrm{KI}+\mathrm{KSCN})$ concentrations reduced biological efficiency.

When the KI/KSCN ration was close to 1 and the total (pseudo)halogen concentration was low, the capacity of the oxidant to inhibit the fungus was lost. This was also observed with low $\mathrm{H}_{2} \mathrm{O}_{2}$ doses. 
Table 7. Total $[\mathrm{KI}+\mathrm{KSCN}]$ dose $(\mathrm{mM}), \mathrm{KI} / \mathrm{KSCN}$ ratio, $\left[\mathrm{KI}+\mathrm{KSCN}+\mathrm{H}_{2} \mathrm{O}_{2}\right]$ doses $(\mathrm{mM})$, dilution factor, percentage of inhibition of $B$. cinerea growth by various doses of $\left(\mathrm{KI}+\mathrm{KSCN}+\mathrm{H}_{2} \mathrm{O}_{2}\right)$ after lactoperoxidase oxidoreduction. The doses were grouped to observe the influence of the total pseudohalogen and halogen concentrations, of the $\mathrm{KI} / \mathrm{KSCN}$ ratio, and of the $\mathrm{H}_{2} \mathrm{O}_{2}$ concentration. Means and s.d. of the two independent trials are given.

\begin{tabular}{|c|c|c|c|c|}
\hline$[\mathrm{KI}+\mathrm{KSCN}](\mathrm{mM})$ & KI/KSCN Ratio & {$\left[\mathrm{KI}-\mathrm{KSCN}-\mathrm{H}_{2} \mathrm{O}_{2}\right](\mathrm{mM})$} & Dilution Factor & B. cinerea Inhibition (\%) \\
\hline \multicolumn{5}{|c|}{ Influence of the total $[\mathrm{KI}+\mathrm{KSCN}]$ concentration } \\
\hline \multirow{3}{*}{$6.6 \mathrm{mM}$} & \multirow{3}{*}{4.5} & $5.4-1.2-6.6$ & $1: 3$ & $88 \pm 5$ \\
\hline & & $5.4-1.2-6.6$ & $1: 5$ & $84 \pm 4$ \\
\hline & & $5.4-1.2-6.6$ & $1: 10$ & $83 \pm 2$ \\
\hline \multirow{3}{*}{$4.4 \mathrm{mM}$} & \multirow{3}{*}{4.5} & $3.6-0.8-3.6$ & $1: 3$ & $88 \pm 5$ \\
\hline & & $3.6-0.8-3.6$ & $1: 5$ & $88 \pm 6$ \\
\hline & & 3.6-0.8-3.6 & $1: 10$ & $70 \pm 11$ \\
\hline \multirow{3}{*}{$3.3 \mathrm{mM}$} & \multirow{3}{*}{4.5} & $2.7-0.6-3.3$ & $1: 3$ & $88 \pm 6$ \\
\hline & & $2.7-0.6-3.3$ & $1: 5$ & $83 \pm 10$ \\
\hline & & $2.7-0.6-3.3$ & $1: 10$ & $34 \pm 1$ \\
\hline \multirow{3}{*}{$5.6 \mathrm{mM}$} & \multirow{3}{*}{7.84} & $5-0.64-5.64$ & $1: 3$ & $92 \pm 0$ \\
\hline & & $5-0.64-5.64$ & $1: 5$ & $69 \pm 11$ \\
\hline & & $5-0.64-5.64$ & $1: 10$ & $42 \pm 6$ \\
\hline \multirow{3}{*}{$3.95 \mathrm{mM}$} & \multirow{3}{*}{7.84} & $3.5-0.45-3.95$ & $1: 3$ & $71 \pm 11$ \\
\hline & & 3.5-0.45-3.95 & $1: 5$ & $42 \pm 5$ \\
\hline & & $3.5-0.45-3.95$ & $1: 10$ & $32 \pm 8$ \\
\hline \multirow{3}{*}{$2.25 \mathrm{mM}$} & \multirow{3}{*}{7.84} & $2-0.25-2.25$ & $1: 3$ & $38 \pm 0$ \\
\hline & & $2-0.25-2.25$ & $1: 5$ & $39 \pm 6$ \\
\hline & & $2-0.25-2.25$ & $1: 10$ & $29 \pm 7$ \\
\hline \multicolumn{5}{|c|}{ Influence of the KI/KSCN ratio } \\
\hline \multirow{3}{*}{$1.12 \mathrm{mM}$} & \multirow{3}{*}{2.3} & $0.78-0.34-1.2$ & $1: 3$ & $90 \pm 4$ \\
\hline & & $0.78-0.34-1.2$ & $1: 5$ & $25 \pm 0$ \\
\hline & & $0.78-0.34-1.2$ & $1: 10$ & $22 \pm 0$ \\
\hline \multirow{3}{*}{$3.9 \mathrm{mM}$} & \multirow{3}{*}{2.25} & $2.7-1.2-3.9$ & $1: 3$ & $84 \pm 1$ \\
\hline & & $2.7-1.2-3.9$ & $1: 5$ & $81 \pm 2$ \\
\hline & & $2.7-1.2-3.9$ & $1: 10$ & $24 \pm 7$ \\
\hline \multirow{3}{*}{$2.95 \mathrm{mM}$} & \multirow{3}{*}{2.25} & $1.35-0.6-1.9$ & $1: 3$ & $87 \pm 3$ \\
\hline & & $1.35-0.6-1.9$ & $1: 5$ & $52 \pm 4$ \\
\hline & & $1.35-0.6-1.9$ & $1: 10$ & $20 \pm 12$ \\
\hline \multirow{3}{*}{$2.4 \mathrm{mM}$} & \multirow{3}{*}{1.1} & $1.35-1.2-2.5$ & $1: 3$ & $28 \pm 4$ \\
\hline & & $1.35-1.2-2.5$ & $1: 5$ & $31 \pm 4$ \\
\hline & & $1.35-1.2-2.5$ & $1: 10$ & $26 \pm 5$ \\
\hline \multirow{3}{*}{$1.3 \mathrm{mM}$} & \multirow{3}{*}{1.1} & $0.67-0.6-1.27$ & $1: 3$ & $16 \pm 6$ \\
\hline & & $0.67-0.6-1.27$ & $1: 5$ & $17 \pm 6$ \\
\hline & & $0.67-0.6-1.27$ & $1: 10$ & $13 \pm 2$ \\
\hline & & uence of the $\mathrm{H}_{2} \mathrm{O}_{2}$ concer & ation & \\
\hline & & $2.16-0.48-0.5$ & $1: 3$ & $10 \pm 7$ \\
\hline $2.64 \mathrm{mM}$ & 4.5 & $2.16-0.48-0.5$ & $1: 5$ & $12 \pm 3$ \\
\hline & & $2.16-0.48-0.5$ & $1: 10$ & $20 \pm 2$ \\
\hline & & $2.16-0.48-1.1$ & $1: 3$ & $39 \pm 3$ \\
\hline $2.64 \mathrm{mM}$ & 4.5 & $2.16-0.48-1.1$ & $1: 5$ & $10 \pm 9$ \\
\hline & & $2.16-0.48-1.1$ & 1:10 & $7 \pm 7$ \\
\hline & & $2.16-0.48-2.7$ & $1: 3$ & $80 \pm 3$ \\
\hline $2.64 \mathrm{mM}$ & 4.5 & $2.16-0.48-2.7$ & $1: 5$ & $45 \pm 5$ \\
\hline & & $2.16-0.48-2.7$ & $1: 10$ & $14 \pm 1$ \\
\hline
\end{tabular}

\section{Discussion}

\subsection{Nature of the Reaction Product}

It is well established that haem-peroxidases oxidize $\mathrm{SCN}^{-}$into $\mathrm{OSCN}^{-}$and $\mathrm{I}^{-}$into $\mathrm{HOI} / \mathrm{I}_{2}$ in the presence of $\mathrm{H}_{2} \mathrm{O}_{2}[9,10]$. While studying biological lactoperoxidase activity in the presence of an $\mathrm{SCN}^{-} / \mathrm{I}^{-}$mixture, a few articles have addressed the products generated under such and such 
experimental conditions $[11,12,21,27]$; several have showed that a more stable oxidative complex was formed in specific $\mathrm{pH}$ and ionic strength conditions [25,27-29]. We found $\mathrm{OSCN}^{-}$after $\mathrm{LPO}$ oxidation of $\mathrm{SCN}^{-}$and $\mathrm{I}_{2}$ after $\mathrm{LPO}$ oxidation of $\mathrm{I}^{-}$. $\mathrm{OSCN}^{-}$is not able to oxidize amine $\left(\mathrm{NH}_{2}\right)$-group $[8,22]$, because of its relatively weak oxidative strength that makes $\mathrm{OSCN}^{-}$specific regarding its molecular target, i.e., a thiol moiety. This implies a lower antimicrobial activity, particularly against fungus, as shown in our study and the reviewed literature $[22,30,31]$. The iodine/hypoiodite ions have a stronger oxidative strength that allows them both to oxidize thiol and amine groups [32-35]. However, its antimicrobial effect can be hampered by the catalytic reaction between iodine and $\mathrm{H}_{2} \mathrm{O}_{2}$, and could explain the low level of oxidant produced and the absence of antifungal activity in our study [36]. In iodide and thiocyanate mixtures, there is a strong competition between $\mathrm{SCN}^{-}$and $\mathrm{I}^{-}$to fix $\mathrm{LPO}$; $\mathrm{I}^{-}$hampers the interaction of $\mathrm{SCN}^{-}$with $\mathrm{LPO}$, inducing a 10-fold increase of the dissociation constant $\left(\mathrm{K}_{\mathrm{D}}\right)$ of $\mathrm{SCN}^{-}$from $\mathrm{LPO}$ [37]. In other words, the affinity of $\mathrm{LPO}$ for $\mathrm{SCN}^{-}$decreases, so that in our experimental conditions the quantity of generated oxidants decreased, too [37]. Based on various distinct techniques, our results show that $\mathrm{OSCN}^{-}, \mathrm{OCN}^{-}$, and $\mathrm{I}_{2}$ were not present as stable oxidants, whereas $\mathrm{SO}_{4}{ }^{2-}$ was a stable byproduct. $\mathrm{SO}_{4}{ }^{2-}$ was measured in high concentrations, demonstrating that $\mathrm{SCN}^{-}$was oxidized. ${ }^{13} \mathrm{C}$ NMR showed that no interhalogen such as $\mathrm{ICN}, \mathrm{I}(\mathrm{SCN})_{2}{ }^{-}$, or I $\mathrm{SCN}^{-}$ was observable $[25,38]$. Anionic chromatography did not detect $\mathrm{OI}^{-}$. $\mathrm{OI}^{-}$stability is relative because aqueous $\mathrm{I}_{2}$ has a very complex behavior; consequently, $\mathrm{OI}^{-}$stability strongly depends on matrix interactions and on the $\mathrm{pH}$ of the medium [8]. The chromatography technique separated each reaction product during the analytical process; this may have reduced $\mathrm{OI}^{-}$stability $[8,39-41]$. On the other hand, the stability of the oxidant, when stored at $4{ }^{\circ} \mathrm{C}$ over a long period of time, its $\mathrm{NH}_{2}$-oxidizing capacity, and its capacity to inhibit fungi, argue in favor of an $\mathrm{I}^{-}$-derived active ion $[8,12,35]$.

\subsection{Influence of Water Mineralization}

Water mineralization strongly influenced on the amount of produced oxidant. Higher mineralization increased the oxidant concentration, especially with concentrated substrate doses. The ratios between the lowest oxidant level, which corresponded to low mineralization, and the highest oxidant level, which corresponded to high mineralization, in the presence of half-dose, full-dose, and double-dose substrates were 1.23, 1.4, and 1.78, respectively, demonstrating that mineralization played a tremendous role in the presence of elevated substrate levels.

The role of minerals has already been showed with ammonium sulfate, which allows horseradish and microbial peroxidases to work more effectively [42]. In particular, both stabilizing and activating effects were found with a cationic surfactant such as benzalkonium chloride [43]. Ammonium sulfate $\left(\left(\mathrm{NH}_{4}\right)_{2} \mathrm{SO}_{4}\right)$ increased LPO activity, therefore positive charges are determining for enzyme activity [43]. The high-mineralized waters used in this study contained high levels of $\mathrm{Ca}^{2+}$ and $\mathrm{Mg}^{2+}$, which could explain why more oxidants were generated. The four waters had similar $\mathrm{pH}$ values and the $\mathrm{pH}$ was unlikely to play a major role in the differences in oxidant concentrations observed among waters through a modification of the reductant potential of Compound I/native LPO [44].

The functionality of haem peroxidases is influenced by the heme $\mathrm{Fe}^{3+} / \mathrm{Fe}^{2+}$ redox couple and by the protein-matrix interaction [45]. In fact, LPO is stabilized by iron-ligand binding interactions, by electrostatic interactions, by the protein environment, and by the solvent [45]. It is important to stabilize and optimize the redox functionality of lactoperoxidase when highly concentrated substrates are used, especially for $\mathrm{H}_{2} \mathrm{O}_{2}$ whose redox couple is elevated [46] and it seems that concentrated minerals in the media optimize the catalytic reaction of LPO when elevated substrate levels are used. Better stabilization of the ferric heme could increase $\mathrm{H}_{2} \mathrm{O}_{2}$ consumption and formation of LPO Compound I, which in turn could induce a higher consumption of iodide and thiocyanate and could finally generate a higher quantity of reaction products. 


\subsection{Influence of the Storage Temperature on the Stability and Antifungal Activity of the Oxidant}

The half-lives of the half dose, full dose, and double dose in several mineralized waters after storage at $4{ }^{\circ} \mathrm{C}$ or $25^{\circ} \mathrm{C}$ are summarized in Table 8 . Cold storage obviously prolonged the stability of the oxidant. Higher substrate doses increased oxidant instability independently of the storage temperature. Higher instability of $\mathrm{OSCN}^{-}$in the presence of higher $\mathrm{SCN}^{-}, \mathrm{H}_{2} \mathrm{O}_{2}$, and $\mathrm{OSCN}^{-}$ concentrations has already been described [12]. Although the nature of the ion was different in our case, it seems to have followed the same principles.

Table 8. Half-lives $\left(\mathrm{T}_{1 / 2}\right)$ expressed in days of the double-, full and half-doses of substrates after lactoperoxidase oxidoreduction in various mineralized waters (low; medium low; medium high; high) in function of the storage temperature $\left(25^{\circ} \mathrm{C}\right.$ or $\left.4{ }^{\circ} \mathrm{C}\right)$.

\begin{tabular}{ccccccc}
\hline & \multicolumn{7}{c}{$\mathbf{T}_{\mathbf{1 / 2}}$ (Days) } \\
\cline { 2 - 7 } & $\mathbf{2 5}{ }^{\circ} \mathbf{C}$ & $\mathbf{4}^{\circ} \mathbf{C}$ & $\mathbf{2 5}^{\circ} \mathbf{C}$ & $\mathbf{4}^{\circ} \mathbf{C}$ & $\mathbf{2 5}^{\circ} \mathbf{C}$ & $\mathbf{4}^{\circ} \mathbf{C}$ \\
\hline Water Mineralization & \multicolumn{2}{c}{ Double-Dose } & \multicolumn{2}{c}{ Full-Dose } & Half-Dose \\
\hline Low & 11 & 34 & 49 & 309 & 109 & 494 \\
Medium Low & 15 & 119 & 36 & 248 & 100 & 464 \\
Medium High & 20 & 165 & 98 & 504 & 73 & 433 \\
High & 33 & 229 & 121 & 491 & 94 & 529 \\
\hline
\end{tabular}

\subsection{Influence of the Relative Substrate Concentrations}

The relative thiocyanate and iodide concentrations turned out to be important. In particular, a higher $\mathrm{I}^{-}$concentration relative to $\mathrm{SCN}^{-}$, enough $\mathrm{H}_{2} \mathrm{O}_{2}$, and a high total amount of $\mathrm{SCN}^{-}$and $\mathrm{I}^{-}$, proved to be important. Enough $\mathrm{H}_{2} \mathrm{O}_{2}$ is obviously necessary to activate the native enzyme in Compound I; this step is essential to oxidize (pseudo)halogens thereafter. If the $\mathrm{H}_{2} \mathrm{O}_{2}$ dose is too low, lower oxidant doses are produced. When iodide is added in lower or similar doses to thiocyanate, iodide interfere with the amount of oxidant produced. As the amount of oxidant decreases, the inhibiting efficiency against $B$. cinerea droped. When iodide and thiocyanate are present, there is a strong competition between $\mathrm{SCN}^{-}$and $\mathrm{I}^{-}$to fix LPO. Therefore, when the two substrates are added to LPO in equal amounts, they most probably inhibit each other through an antagonism between $\mathrm{I}^{-}$ and $\mathrm{SCN}^{-}$to fix the binding site of lactoperoxidase [12]. Increased oxidant quantities are produced with elevated substrates and the better inhibition observed in this case is probably due to a dose effect, as already observed with other pathogens [11].

\section{Conclusions}

The literature shows that the LPO-catalyzed oxidation of $\mathrm{I}^{-}$and $\mathrm{SCN}^{-}$mixtures can result in contradictory antimicrobial efficiency. The present article shows that certain mixtures of lactoperoxidase-oxidized $\mathrm{I}^{-}$and $\mathrm{SCN}^{-}$have a very good antimicrobial potential. Practical applications should use an optimal iodide/thiocyanate ratio of 4.5 to favor antimicrobial efficiency and a strongly mineralized medium if high doses of substrates are used. Although the oxidant is relatively stable, its long-term storage is clearly improved at $4{ }^{\circ} \mathrm{C}$. The use of an environment that enhances the oxidoreduction reaction catalyzed by the enzyme can dramatically increase its efficiency; as a consequence, more oxidants are generated and antimicrobial activity is better.

Author Contributions: Conceptualization, F.B., M.H.J., and J.-P.P.; methodology, F.B., M.H.J., and J.-P.P.; software, F.B. and C.D.; data validation, F.B., C.D., G.C.L., and J.-P.B.; formal analysis, F.B., C.D., G.C.L., and J.-P.B.; writing—original draft preparation, F.B.; writing—review and editing, F.B., M.H.J., C.D., G.C.L., J.-P.B., and J.-P.P.; supervision, M.H.J.; project administration, F.B. and M.H.J.

Funding: This research was funded by the Walloon Region (Service Public de Wallonie-DGO6) and by Taradon Laboratory.

Conflicts of Interest: The authors declare no conflict of interest. 


\section{References}

1. Jijakli, M.H.; Lepoivre, P. State of the Art and Challenges of Post-harvest Disease Management in Apples. In Disease Management in Fruits and Vegetables; Mukerij, K.G., Ed.; Springer Netherlands: Cham, The Netherlands, 2004; Volume 1, pp. 59-94.

2. Snini, S.P.; Tannous, J.; Heuillard, P.; Bailly, S.; Lippi, Y.; Zehraoui, E.; Barreau, C.; Oswald, I.P.; Puel, O. Patulin is a cultivar-dependent aggressiveness factor favouring the colonization of apples by Penicillium expansum. Mol. Plant Pathol. 2016, 17, 920-930. [CrossRef]

3. Sanzani, S.M.; Reverberi, M.; Punelli, M.; Ippolito, A.; Fanelli, C. Study on the role of patulin on pathogenicity and virulence of Penicillium expansum. Int. J. Food Microbiol. 2012, 153, 323-331. [CrossRef]

4. ANSES. Étude Nationale de Surveillance des Expositions Alimentaires aux Substances Chimiques-2e Étude de L'alimentation Totale 2006-2010 (EAT 2). Tome 1: Contaminants Inorganiques, Minéraux, Polluants Organiques Persistants, Mycotoxines et Phyto-Estrogènes; ANSES: Buenos Aires, Argentina, 2011.

5. Tenovuo, J.; Makinen, K.K.; Sievers, G. Antibacterial effect of lactoperoxidase and myeloperoxidase against Bacillus cereus. Antimicrob. Agents Chemother. 1985, 27, 96-101. [CrossRef] [PubMed]

6. Bjorck, L.; Claesson, O. Correlation between concentration of hypothiocyanate and antibacterial effect of the lactoperoxidase system against Escherichia coli. J. Dairy Sci. 1980, 63, 919-922. [CrossRef]

7. Oram, J.D.; Reiter, B. The inhibition of streptococci by lactoperoxidase, thiocyanate and hydrogen peroxide. The effect of the inhibitory system on susceptible and resistant strains of group N streptococci. Biochem. J. 1966, 100, 373-381. [CrossRef] [PubMed]

8. Bafort, F.; Parisi, O.; Perraudin, J.-P.; Jijakli, M.H. Mode of Action of Lactoperoxidase as Related to Its Antimicrobial Activity: A Review. Enzyme Res. 2014, 2014, 517164. [CrossRef] [PubMed]

9. Aune, T.M.; Thomas, E.L. Accumulation of hypothiocyanite ion during peroxidase-catalyzed oxidation of thiocyanate ion. Eur. J. Biochem. 1977, 80, 209-214. [CrossRef] [PubMed]

10. Thomas, E.L.; Aune, T.M. Peroxidase-catalyzed oxidation of protein sulfhydryls mediated by iodine. Biochemistry 1977, 16, 3581-3586. [CrossRef] [PubMed]

11. Bafort, F.; Parisi, O.; Perraudin, J.-P.; Jijakli, M.H. The Lactoperoxidase System: A Natural Biochemical Biocontrol Agent for Pre- and Postharvest Applications. J. Phytopathol. 2017, 165, 22-34. [CrossRef]

12. Pruitt, K.M.; Tenovuo, J.O. The lactoperoxidase system: Chemistry and biological significance. Immunol. Ser. 1985, 27, 96-101.

13. Ahariz, M.; Courtois, P. Candida albicans susceptibility to lactoperoxidase-generated hypoiodite. Clin. Cosmet. Investig. Dent. 2010, 2, 69-78.

14. Fonteh, F.A.; Grandison, A.S.; Lewis, M.J. Variations of lactoperoxidase activity and thiocyanate content in cows' and goats' milk throughout lactation. J. Dairy Res. 2002, 69, 401-409. [CrossRef]

15. Kussendrager, K.D.; van Hooijdonk, A.C. Lactoperoxidase: Physico-chemical properties, occurrence, mechanism of action and applications. Br. J. Nutr. 2000, 84 (Suppl. 1), S19-S25. [CrossRef]

16. Boots, J.W.; Floris, R. Lactoperoxidase: From catalytic mechanism to practical applications. Int. Dairy J. 2006, 16, 1272-1276. [CrossRef]

17. van Hooijdonk, A.C.; Kussendrager, K.D.; Steijns, J.M. In vivo antimicrobial and antiviral activity of components in bovine milk and colostrum involved in non-specific defence. Br. J. Nutr. 2000, 84 (Suppl. 1), S127-S134. [CrossRef]

18. Lenander-Lumikari, M.; Tenovuo, J.; Mikola, H. Effects of a lactoperoxidase system-containing toothpaste on levels of hypothiocyanite and bacteria in saliva. Caries Res. 1993, 27, 285-291. [CrossRef]

19. Kirstila, V.; Lenander-Lumikari, M.; Soderling, E.; Tenovuo, J. Effects of oral hygiene products containing lactoperoxidase, lysozyme, and lactoferrin on the composition of whole saliva and on subjective oral symptoms in patients with xerostomia. Acta Odontol. Scand. 1996, 54, 391-397. [CrossRef] [PubMed]

20. Gil-Montoya, J.A.; Guardia-Lopez, I.; Gonzalez-Moles, M.A. Evaluation of the clinical efficacy of a mouthwash and oral gel containing the antimicrobial proteins lactoperoxidase, lysozyme and lactoferrin in elderly patients with dry mouth-A pilot study. Gerodontology 2008, 25, 3-9. [CrossRef] [PubMed]

21. Ihalin, R.; Loimaranta, V.; Lenander-Lumikari, M.; Tenovuo, J. The effects of different (pseudo)halide substrates on peroxidase-mediated killing of Actinobacillus actinomycetemcomitans. J. Periodontal Res. 1998, 33, 421-427. [CrossRef] 
22. Bafort, F.; Barthelemy, J.-P.; Parisi, O.; Perraudin, J.-P.; Jijakli, H. Development of a colorimetric method for the dosage of $\mathrm{OI}^{-}$anions and $\mathrm{I}_{2}$ in aqueous media. Commun. Agric. Appl. Biol. Sci. 2014, 79, 155-160. [PubMed]

23. WHO; UNICEF; ICCIDD. Assessment of Iodine Deficiency Disorders and Monitoring Their Elimination. A Guide for Programme Managers; WHO Press: Geneva, Switzerland, 2007.

24. Nagy, P.; Alguindigue, S.S.; Ashby, M.T. Lactoperoxidase-catalyzed oxidation of thiocyanate by hydrogen peroxide: A reinvestigation of hypothiocyanite by nuclear magnetic resonance and optical spectroscopy. Biochemistry 2006, 45, 12610-12616. [CrossRef] [PubMed]

25. Bafort, F.; Damblon, C.; Smargiasso, N.; De Pauw, E.; Perraudin, J.-P.; Jijakli, M.H. Reaction product variability and biological activity of the lactoperoxidase system depending on medium ionic strength and $\mathrm{pH}$, and on substrate relative concentration. Chem. Biodivers. 2018, 15, e170049. [CrossRef] [PubMed]

26. Arlandson, M.; Decker, T.; Roongta, V.A.; Bonilla, L.; Mayo, K.H.; MacPherson, J.C.; Hazen, S.L.; Slungaard, A. Eosinophil peroxidase oxidation of thiocyanate. Characterization of major reaction products and a potential sulfhydryl-targeted cytotoxicity system. J. Biol. Chem. 2001, 276, 215-224. [CrossRef] [PubMed]

27. Bosch, E.H.; van Doorne, H.; de Vries, S. The lactoperoxidase system: The influence of iodide and the chemical and antimicrobial stability over the period of about 18 months. J. Appl. Microbiol. 2000, 89, 215-224. [CrossRef] [PubMed]

28. Schlorke, D.; Flemmig, J.; Birkemeyer, C.; Arnhold, J. Formation of cyanogen iodide by lactoperoxidase. J. Inorg. Biochem. 2016, 154, 35-41. [CrossRef] [PubMed]

29. Sebaa, S.; Faltot, M.; De Breucker, S.; Boucherit-Otmani, Z.; Bafort, F.; Perraudin, J.-P.; Courtois, P. Ex vivo decontamination of yeast-colonized dentures by iodine-thiocyanate complexes. Clin. Cosmet. Investig. Dent. 2018, 10, 149-158. [CrossRef]

30. Aune, T.M.; Thomas, E.L. Oxidation of protein sulfhydryls by products of peroxidase-catalyzed oxidation of thiocyanate ion. Biochemistry 1978, 17, 1005-1010. [CrossRef]

31. Thomas, E.L.; Aune, T.M. Lactoperoxidase, peroxide, thiocyanate antimicrobial system: Correlation of sulfhydryl oxidation with antimicrobial action. Infect. Immun. 1978, 20, 456-463.

32. Thomas, E.L.; Aune, T.M. Oxidation of Escherichia coli sulfhydryl components by the peroxidase-hydrogen peroxide-iodide antimicrobial system. Antimicrob. Agents Chemother. 1978, 13, 1006-1010. [CrossRef]

33. Prütz, W.A.; Kissner, R.; Nauser, T.; Koppenol, W.H. On the oxidation of cytochrome c by hypohalous acids. Arch. Biochem. Biophys. 2001, 389, 110-122. [CrossRef]

34. Prütz, W.A.; Kissner, R.; Koppenol, W.H.; Rüegger, H. On the irreversible destruction of reduced nicotinamide nucleotides by hypohalous acids. Arch. Biochem. Biophys. 2000, 380, 181-191. [CrossRef]

35. Ashby, M.T. Chapter 8-Hypothiocyanite. Adv. Inorg. Chem. 2012, 64, 263-303.

36. Magnusson, R.P.; Taurog, A.; Dorris, M.L. Mechanism of iodide-dependent catalatic activity of thyroid peroxidase and lactoperoxidase. J. Biol. Chem. 1984, 259, 197-205.

37. Ferrari, R.P.; Ghibaudi, E.M.; Traversa, S.; Laurenti, E.; De Gioia, L.; Salmona, M. Spectroscopic and binding studies on the interaction of inorganic anions with lactoperoxidase. J. Inorg. Biochem. 1997, 68, 17-26. [CrossRef]

38. Long, C.; Skoog, D.A. A Thiocyanate Complex of Iodine(I). Inorg. Chem. 1966, 5, 206-210. [CrossRef]

39. Gottardi, W. Iodine and disinfection: Theoretical study on mode of action, efficiency, stability, and analytical aspects in the aqueous system. Arch. Pharm. 1999, 332, 151-157. [CrossRef]

40. Bichsel, Y.; Von Gunten, U. Oxidation of iodide and hypoiodous acid in the disinfection of natural waters. Environ. Sci. Technol. 1999, 33, 4040-4045. [CrossRef]

41. Bichsel, Y.; Von Gunten, U. Hypoiodous acid: Kinetics of the buffer-catalyzed disproportionation. Water Res. 2000, 34, 3197-3203. [CrossRef]

42. Holm, K.A. Automated determination of microbial peroxidase activity in fermentation samples using hydrogen peroxide as the substrate and 2,2' -azino-bis(3-ethylbenzothiazoline-6-sulfonate) as the electron donor in a flow injection system. Analyst 1995, 120, 2101-2105. [CrossRef]

43. Marcozzi, G.; Di Domenico, C.; Spreti, N. Effects of surfactants on the stabilization of the bovine lactoperoxidase activity. Biotechnol. Prog. 1998, 14, 653-656. [CrossRef]

44. Arnhold, J.; Monzani, E.; Furtmüller, P.G.; Zederbauer, M.; Casella, L.; Obinger, C. Kinetics and thermodynamics of halide and nitrite oxidation by mammalian heme peroxidases. Eur. J. Inorg. Chem. 2006, 19, 3801-3811. [CrossRef] 
45. Battistuzzi, G.; Bellei, M.; Vlasits, J.; Banerjee, S.; Furtmüller, P.G.; Sola, M.; Obinger, C. Redox thermodynamics of lactoperoxidase and eosinophil peroxidase. Arch. Biochem. Biophys. 2010, 494, 72-77. [CrossRef]

46. Furtmüller, P.G.; Arnhold, J.; Jantschko, W.; Zederbauer, M.; Jakopitsch, C.; Obinger, C. Standard reduction potentials of all couples of the peroxidase cycle of lactoperoxidase. J. Inorg. Biochem. 2005, 99, 1220-1229. [CrossRef] 